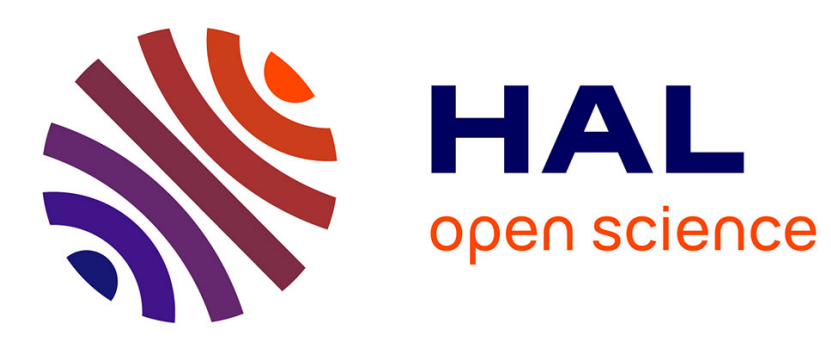

\title{
Mitochondrial control of apoptosis
}

Bernard Mignotte, Jean-Luc Vayssière

\section{To cite this version:}

Bernard Mignotte, Jean-Luc Vayssière. Mitochondrial control of apoptosis. M.P. Mattson. Programmed Cell Death Vol I: Cellular and Molecular Mechanisms., Elsevier, pp.93-122, 2001, Cell Aging and Gerontology, Vol 5, 3-540-64177-7. hal-03002780

\section{HAL Id: hal-03002780 \\ https://hal.science/hal-03002780}

Submitted on 16 Dec 2020

HAL is a multi-disciplinary open access archive for the deposit and dissemination of scientific research documents, whether they are published or not. The documents may come from teaching and research institutions in France or abroad, or from public or private research centers.
L'archive ouverte pluridisciplinaire HAL, est destinée au dépôt et à la diffusion de documents scientifiques de niveau recherche, publiés ou non, émanant des établissements d'enseignement et de recherche français ou étrangers, des laboratoires publics ou privés. 


\title{
MITOCHONDRIAL CONTROL OF APOPTOSIS \\ Bernard MIGNOTTE, Jean-Luc VAYSSIERE
}

Abbreviated title: mitochondrial control of apoptosis

Adress:

Laboratoire Génome, Cellule et Informatique, Université de Versailles/SaintQuentin

45 avenue des Etats Unis, 78035 VERSAILLES cedex

Phone: (33) 139253650

Fax: (33) 139253655

E-mail : mignotte@genetique.uvsq.fr

\begin{abstract}
Abbreviations: $\Delta \Psi \mathrm{m}$, mitochondrial membrane potential; PCD, programmed cell death; PT, permeability transition; ROS, reactive oxygen species; DEVD, acetyl-Asp-Glu-Val-Asp-aldehyde; TNF- $\alpha$, tumor necrosis factor- $\alpha$; SOD, superoxide dismutase; NGF, nerve growth factor; AIF, apoptosis inducing factor; Apaf-1, apoptosis protease-activating factor 1; ANT, adenine nucleotides translocase; GSH, glutathione.
\end{abstract}


$\begin{array}{lc}\text { INTRODUCTION } & 4\end{array}$

$\begin{array}{ll}\text { The actors of the execution stage of the apoptotic cascade } & 4\end{array}$

Bcl-2 family proteins act at least in part at the mitochondrial level 6

PERMEABILITY TRANSITION MARKS A POINT OF NO-RETURN OF CELLS CONDEMNED TO DIE 10

A decrease in mitochondrial membrane potential precedes DNA fragmentation

$\begin{array}{lr}\text { during apoptosis } & 10\end{array}$

Mitochondrial permeability transition provokes a $\Delta \Psi_{\mathrm{m}}$ decrease $\quad 11$

Direct interventions on the mitochondrial permeability transition modulate apoptosis 12

MITOCHONDRIA OF CELLS UNDERGOING APOPTOSIS RELEASE PRO-APOPTOTIC FACTORS 14

Mitochondria undergoing permeability transition liberate AIF factor. $\quad 14$

$\begin{array}{ll}\text { Cytochrome } \mathrm{c} \text { is released by mitochondria during apoptosis } & 15\end{array}$

$\begin{array}{ll}\text { The cytochrome c pathway is distinct from that of AIF } & 18\end{array}$

$\begin{array}{ll}\text { Bcl-2 family proteins dock various proteins to the mitochondria } & 19\end{array}$

What is the mechanism involved in cytoplasmic release of mitochondrial apoptogenic

$\begin{array}{ll}\text { factors? } & 22\end{array}$

$\begin{array}{lr}\text { MITOCHONDRIAL ROS AND APOPTOSIS SIGNALLING } & 24\end{array}$

ROS as mediators of PCD $\quad 24$

$\begin{array}{ll}\text { PCD-mediating ROS are produced by mitochondria } & 27\end{array}$

$\begin{array}{lr}\text { Mechanisms of ROS signaling } & 29\end{array}$

$\begin{array}{lr}\text { CONCLUSIONS } & 34\end{array}$

$\begin{array}{lr}\text { REFERENCES } & 36\end{array}$ 


\begin{abstract}
Programmed cell death (PCD) serves as a major mechanism for the precise regulation of cell numbers, and as a defense mechanism to remove unwanted and potentially dangerous cells. Despite the striking heterogeneity of cell death induction pathways, the execution of the death program is often associated with characteristic morphological and biochemical changes termed apoptosis. In both worm and mammalian cells, the antiapoptotic members of the Bcl-2 family act upstream of the "execution caspases" somehow preventing their proteolytic processing into active killers.

Two main pathways connect Bcl-2 family proteins to caspases. In the first one, antiapoptotic Bcl-2 family proteins maintain cell survival by dragging execution caspases to intracellular membranes (probably the mitochondrial membrane) and by preventing their activation. The mammalian protein Apaf-1, the mammalian equivalent of CED-4, could be the physical link between Bcl-2 family proteins and caspases. In the second one, Bcl-2 would act by regulating the release from mitochondria of caspases activators: cytochrome $\mathrm{c}$ and/or AIF (Apoptosis-Inducing-Factor). This crucial position of mitochondria in PCD control is reinforced by the observation that mitochondria contribute to PCD signaling via the production of reactive oxygen species, as shown in TNF- $\alpha$ - or ceramide-induced cell death during which increased mitochondrial ROS production appears as an early event of the induction phase. In this chapter, we examine the data concerning the mitochondrial features of PCD.
\end{abstract}

\title{
Key words :
}

Programmed cell death / apoptosis / caspase / mitochondria / Bcl-2 


\section{INTRODUCTION}

\section{The actors of the execution stage of the apoptotic cascade}

The programmed cell death cascade can be conveniently divided into several phases. During the activation phase, multiple signaling pathways lead from the various death-triggering signals to the central control of the cell death machinery and activate it. This is followed by the execution stage, in which the activated machinery acts on multiple cellular targets, and, finally, the destruction phase in which the dead or dying cell is broken down.

A most important clue to the molecular nature of the death program came initially from genetic studies in C. elegans that led to the identification of a dozen cell death genes (ced) that are responsible for one aspect or another of cell death processes (Ellis et al., 1991). Three of these genes stand out. Two, ced-3 and ced-4 are essential for cell death. The third, ced-9, antagonizes the death activities of $c e d-3$ and ced-4.

Mutational analyses of these genes had been placed ced-4 between ced-9 and ced-3 in the pathway leading to cell death, suggesting that CED-4 might act as an adaptator, linking the upstream regulator CED-9 to the downstream death effector CED-3 (Shaham and Horvitz, 1996). Biochemical approaches have provided insight into the mechanism by which programmed cell death is regulated in the nematode. CED-4 interacts directly and simultaneously with both CED-3 and CED-9 forming a multimeric protein complex (Chinnaiyan et al., 1997b; Wu et al., 1997a). Furthermore, oligomerized CED-4, acting as a context dependent ATPase, promotes CED3's activation and its ability to induced apoptosis (Chinnaiyan et al., 1997a). CED-9 binding to CED-4, mutually exclusive with CED-4 oligomerization, 
prevents it from activating CED-3, thereby blocking cell death (Yang et al., 1998). Remarkably, all three of these C. Elegans cell death genes have mammalian counterparts that are likely to play similar, albeit more complex, roles in mammalian cell death (Table 1). CED-3 protein turned out to be a member of a family of cystein proteases, known as caspases (cystein aspartases). The mammalian caspase family now comprises at least ten known members, most of which have been definitively implicated in PCD (for review see(Cryns and Yuan, 1998)). All cleave their substrates after specific aspartic acids and are themselves activated by cleavage at specific aspartic acids (Nicholson and Thornberry, 1997). Caspases mediate PCD by cleaving selected intracellular proteins, including proteins of the nucleus, nuclear lamina, cytoskeleton, endoplasmic reticulum, and cytosol. However, which of these targets is, if any, responsible for the cell blebbing, condensation and fragmentation that characterize PCD remains uncertain. As specific protein or peptide caspase inhibitors can block PCD in all animal and invertebrate cells and in most cell death inducing conditions, it seems likely that caspases form the core of the death program.

Recent studies have identified and partially characterized Apaf-1 (Apoptotic protease-activating factor-1), a mammalian homologue of $C$. elegans CED-4 (Zou et al., 1997). The N-terminal region of Apaf-1 shares amino acid homology with CED-4 and several caspases with long prodomains, including, caspase-4. -8. -9, and CED-3. This conserved region, that has been termed caspase recruitment domain (CARD), mediates the physical association of CARD-containing proteins (Hofmann et al., 1997). Thus, Ced-4 binding to Ced-3 involves their respective amino-terminal protein interaction modules. In a such way, Apaf-1 was shown to interact with caspase-9, a mammalian caspase containing a $\mathrm{N}$-terminal long prodomain, and to trigger caspase-9 proteolytic self-activation ( $\mathrm{Li}$ et al., 1997b). Caspase-9 subsequently 
proteolyses and activates caspase-3, one of the execution caspases which kill the cell by cleaving key intracellular death targets.

\section{Bcl-2 family proteins act at least in part at the mitochondrial level}

CED-9 protein is homologous to a family of many members termed the Bcl-2 family in reference to the first discovered mammalian cell death regulator (for review see (Adams and Cory, 1998)). Some members, such as Bcl-2 or Bcl- $\mathrm{x}_{\mathrm{L}}$, are negative regulators of cell death, able to prevent cells from undergoing apoptosis induced by various stimuli in a wide variety of cell types (Korsmeyer, 1992; Zhong et al., 1993), whereas others, such as Bax, Bid and Egl-1 promote or accelerate cell death. All members possess at least one of four conserved motifs known as Bcl-2 homology domain (BH1 to BH4). Most pro-survival members contain at least $\mathrm{BH} 1$ and $\mathrm{BH} 2$, and those most similar to Bcl-2 have all four BH domains. Two pro-apoptotic subfamilies can be define according to their relatedness to Bcl-2. Bax, Bak and Bok, which contain $\mathrm{BH} 1, \mathrm{BH} 2$ and $\mathrm{BH} 3$, resemble Bcl-2 fairly closely. In contrast, the other known mammalian and nematode EGL-1 "killers" possess only the central $\mathrm{BH} 3$ domain. These "BH3 domain" proteins may represent the physiological antagonists of the pro-survival proteins, because programmed cell death in $C$. elegans requires Egl-1, which binds to and acts via CED-9. BH3 is essential for the function of the "killers", including Egl-1.

The various family members (referred to here as Bcl-2s) can heterodimerize and seemingly titrate one another's function, suggesting that their relative concentration may act as a rheostat for the suicide program. Heterodimerization is not required for pro-survival function. For pro-apoptotic activity, heterodimerization is essential in the $\mathrm{BH} 3$ domain group, but less so for those of the Bax group, which may have an independent cytotoxic impact. 
Indeed whether Bax binds to Bcl-2 inside cells has become controversial. Some death agonists may preferentially target subsets of the death repressors. Bok, for example, interacts with Mcl-1 and the Epstein-barr viral protein BHFR1 but not with $\mathrm{Bcl}-2$ or $\mathrm{Bcl}-\mathrm{x}_{\mathrm{L}}$. Within the $\mathrm{BH} 3$ group, Bid is promiscuous, binding to Bax and Bak as well as to the anti-apoptotic proteins, but the others bind only to certain of the death inhibitors.

However, the mechanism(s) by which proteins of the Bcl-2 family modulate apoptosis remains elusive and several conflicting theories have been proposed. A widely accepted model postulates that homodimers of Bax promote apoptosis, and that the functional effect of Bcl-2 related proteins is to form competing heterodimers with Bax that cannot promote apoptosis (Oltvai et al., 1993; Sedlak et al., 1995). However, in some systems, Bax binding by Bcl-2 was not sufficient to prevent apoptosis and the overexpression of Bcl-2 or Bcl- $x_{L}$ can repress apoptosis in the absence of Bax (Cheng et al., 1996; Knudson and Korsmeyer, 1997). Thus, while an in vivo competition exists between Bax and Bcl-2, each is able to regulate apoptosis independently.

CED-9, Bcl-2 (Akao et al., 1994; Chen et al., 1989; de Jong et al., 1994; Hockenbery et al., 1990; Janiak et al., 1994; Krajewski et al., 1993; Nakai et al., 1993; Nguyen et al., 1993), Bcl-x ${ }_{L}$ (Gonzalez-Garcia et al., 1994), Mcl-1 (Wang and Studzinski, 1997; Yang et al., 1995), the BHRF1 EpsteinBarr virus protein (Hickish et al., 1994) and probably other members of the Bcl-2 family are localized to the cytoplasmic surfaces of the nuclear envelope, the endoplasmic reticulum and the outer mitochondrial membrane. However, it must be underlined that only a fraction of $\mathrm{Bcl}-\mathrm{x}_{\mathrm{L}}$ resides on membranes, and that Bax seems to be cytosolic before an apoptotic stimulus, even though both, like most other family members, bear a C-terminal membrane anchor. The membrane association of $\mathrm{Bcl}-2$ is of functional significance as mutant Bcl-2 molecules lacking this membrane anchorage capacity are less effective at 
preventing apoptosis in some systems (Borner et al., 1994; Nguyen et al., 1994; Zhu et al., 1996). Indeed, it has been reported that, in inhibiting apoptosis of MDCK cells, a mutant Bcl-2 molecule whose anchorage is targeted specifically to the mitochondria is as effective as the wild type protein, whereas mutant Bcl-2 targeted to the ER loses this capacity (Zhu et al., 1996). In contrast, Bcl-2 targeted to the ER in the Rat-1/myc fibroblasts proved to be more active than when targeted to mitochondria. Thus, Bcl-2 mutants with restricted subcellular location reveal distinct pathways for apoptosis depending on cell type. When associated to the endoplasmic reticulum membrane, Bcl-2 could be involved in maintenance of the calcium homeostasis (Distelhorst et al., 1996; He et al., 1997; Lam et al., 1994), while it could modulate protein subcellular trafficking through nuclear pores (Ryan et al., 1994).

Recent reports provide spectacular advancements in the understanding of the mechanism of action of antiapoptotic Bcl-2s. It was shown that, in both worm and mammalian cells, the antiapoptotic Bcl-2s act upstream of the "execution caspases" somehow preventing their proteolytic processing into active killers (Golstein, 1997; Shaham and Horvitz, 1996). How these proteins perform this feat remains unknown although two main mechanisms of action have been proposed to connect Bcl-2s to caspases.

In the first one, pro-survival proteins would act by regulating the release of some caspases activators usually sequestered in intracellular compartments. Apoptosis (in vivo and in vitro) involved the preliminary shift to the cytosol of regulatory components, namely cytochrome $\mathrm{c}$ or AIF (Apoptosis-Inducing-Factor), previously sequestered in mitochondrial intermembrane space (Kluck et al., 1997a; Susin et al., 1996; Yang et al., 1997). Cytosolic cytochrome c forms an essential part of the vertebrate "apoptosome" which is composed of cytochrome c, Apaf-1 and procaspase-9 
(Li et al., 1997b). The result is the activation of caspase-9, which then activates other caspases to orchestrate execution of cell death. AIF (Apoptosisinducing factor) is another caspase-activating protein which promotes nuclear apoptosis in vitro probably via the activation of procaspase-3, a major executive caspase. Overexpression of $\mathrm{Bcl}-2 / \mathrm{Bcl}-\mathrm{x}_{\mathrm{L}}$ in cells or addition of recombinant $\mathrm{Bcl}-2$ to cell-free systems containing mitochondria prevented cytochrome c/AIF's exodus from the mitochondria that was trigerred normally by a wide variety of apoptogenic stimuli. In contrast, the pro-apoptotic member Bax stimulates mitochondrial cytochrome $\mathrm{c}$ release. The ability of $\mathrm{Bax}, \mathrm{Bcl}-2 / \mathrm{Bcl}-\mathrm{X}_{\mathrm{L}}$ to form membranes pores with distinct ion-conducting properties may provide a clue to how Bcl-2s can regulate the permeability of the intracellular membranes (Reed, 1997).

An alternative model proposes that the pro-survival proteins may function downstream the release of apoptogenic factors, by directly inhibiting the ability of CED-4 like proteins to activate caspases. This model arose from the elucidation of the role of the somewhat mysterious CED-4 protein (Hengartner, 1997). Indeed, it was first shown that CED-9 interacts with CED3 via the bridging protein CED-4 that binds simultaneously to CED-9 and CED-3. CED-9 prevents CED-4 from inducing proteolytic processing and activation of CED-3 (Chinnaiyan et al., 1997b; Wu et al., 1997b). These observations, concerning developmental cell death in C. elegans, were extended to mammalian PCD (Chinnaiyan et al., 1997b). An equivalent ternary complex was found to be present in mammalian cells involving Apaf-

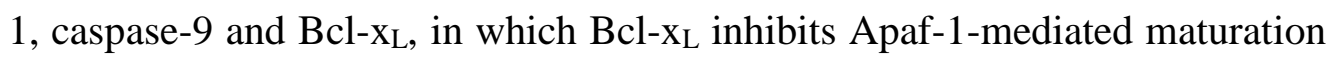
of caspase-9. In this paradigm, pro-apoptotic relatives like Bik may free CED4/Apaf-1 from the death inhibitor. Furthermore, there is some evidence that binding of pro-survival proteins to the apoptosome complex alter its location 
in cells, pulling it from the cytosol to the intracellular membranes where Bcl2s often reside (Chinnaiyan et al., 1997b; Wu et al., 1997b).

Thus, the mitochondrion seems to constitute a pivot component of all the mechanisms of activation either as docking sites, via Bcl-2 family proteins, of caspases or as sequestering organelles of caspase activators. This crucial position of mitochondria in PCD control may be reinforced by the results obtained from distinct approaches establishing that mitochondria can contribute to PCD via the production of cell death signaling ROS. This chapter examines the data concerning the mitochondrial features of PCD and the way by which Bcl-2 family proteins participates in the modulation of these mitochondrial events (recent reviews on similar subjects: (Mignotte and Vayssière, 1998; Zamzami et al., 1998)).

\section{PERMEABILITY TRANSITION MARKS A POINT OF NO-RETURN OF CELLS CONDEMNED TO DIE}

\section{A decrease in mitochondrial membrane potential precedes DNA fragmentation during apoptosis}

Several changes in mitochondrial biogenesis and function are associated with the commitment to apoptosis. A fall of the membrane potential $(\Delta \Psi \mathrm{m})$ occurs before the fragmentation of the DNA in oligonucleosomal fragments (Kroemer et al., 1995; Petit et al., 1995; Vayssière et al., 1994; Zamzami et al., 1995a; Zamzami et al., 1995b). This drop of $\Delta \Psi_{\mathrm{m}}$ is responsible for a defect of maturation of mitochondrial proteins synthesized in the cytoplasm (Mignotte et al., 1990), cessation of mitochondrial translation and an uncoupling of the oxidative phosphorylations (Vayssière et al., 1994). The drop of $\Delta \Psi_{\mathrm{m}}$ is detectable whatever the apoptosis induction signal, 
physiological (absence of growth factor, glucocorticoids, TNF) or nonphysiological (irradiation, chemotherapy). These data showed on the one hand that the nuclear fragmentation is a late event as compared to the drop of the $\Delta \Psi_{\mathrm{m}}$ and, on the other hand, that this drop marks the point of no-return of a cell condemned to die.

\section{Mitochondrial permeability transition provokes a $\Delta \Psi_{\mathrm{m}}$ decrease}

What is the mechanism involved in the $\Delta \Psi_{\mathrm{m}}$ disruption? The permeability transition (PT) is a phenomenon that is characterized by the opening of large conductance channels known as the mitochondrial PT pores and by its sensitivity to very low concentration of cyclosporine A. These pores, permeable to compounds of molecular mass up to $1500 \mathrm{Da}$ are formed under specific conditions. The opening of these PT pores in the inner membrane allows for an equilibration of ions within the matrix and intermembrane space of mitochondria, thus dissipating the $\mathrm{H}+$ gradient across the inner membrane and uncoupling the respiratory chain. These events lead to the decrease of the $\Delta \Psi_{\mathrm{m}}$ and the arrest of ATP synthesis (Bernardi et al., 1992; Petronilli et al., 1994). Perhaps more importantly, PT pore opening results in a

volume dysregulation of mitochondria due to the hyperosmolarity of the matrix, which cause the matrix space to expand. Because the inner membrane a larger surface area than the outer membrane, this matrix volume expansion can eventually provokes outer membrane rupture, releasing intermembrane space molecules into the cytosol. Furthermore, permeability transition has properties of self-amplification: the drop of the $\Delta \Psi_{\mathrm{m}}$ that is linked to depletion of non-oxidized glutathione (Macho et al., 1997), and that result from the opening of the PT pores would increase the permeability transition in a retrograde manner. We have therefore proposed that the opening of the PT pore may constitute an irreversible state of apoptosis and could account for the 
apparent synchronization in the drop of $\Delta \Psi_{\mathrm{m}}$ that takes place simultaneously in all the mitochondria of a same cell (Kroemer et al., 1995). The molecular composition of these PT pores remains elusive. The peripheral benzodiazepin receptor, that has recently been implicated in the protection against ROS (Carayon et al., 1996), and the translocase of adenine nucleotides (ANT) are

probable components of the PT pore. Indeed, protoporphyrine IX and PK11195, that are ligands of the benzodiazepin receptor, induce a drop of $\Delta \Psi_{\mathrm{m}}$ and consequently apoptosis (Hirsch et al., 1998; Zamzami et al., 1996a). On the contrary, N-methyl Val-4-cyclosporin A (a derivative of cyclosporine that is not immunosuppressor) and bongkrekic acid that bind to the matrix side of the ANT, prevent the drop of the mitochondrial potential. Altogether, these results sustain the hypothesis that the opening of PT pores is involved in the disruption of $\Delta \Psi_{\mathrm{m}}$ observed during apoptosis.

\section{Direct interventions on the mitochondrial permeability transition modulate apoptosis}

Direct alterations of mitochondria can induce apoptosis (Hartley et al., 1994; Wolvetang et al., 1994). The links between mitochondrial perturbations and nuclear alterations have been studied by means of acellular systems where purified nuclei and purified mitochondria are confronted (Newmeyer et al., 1994). Such a system allows to study reciprocal and direct effects of one organelle on another and to characterize at the biochemical level the factors involved.

These experiments have shown that when mitochondria are treated with substances capable to induce PT pores opening, they provoke nuclear apoptosis (condensation of the chromatin and fragmentation of the DNA) (Zamzami et al., 1996b). A correlation between induction of the PT and nuclear apoptosis has been observed by using a variety of known inductors of 
the PT such as atractyloside, pro-oxidants, calcium, protonophores and substances that provoke linkage of thiol groups such as diamide. These substances, that have no direct effect on nuclei in absence of mitochondria, confer pro-apoptotic properties upon mitochondria. The pro-apoptotic character (induction of nuclear apoptosis) of the mitochondria treated with atractyloside is altered by inhibitors of the PT such as bongkrekic acid, cyclosporine A and substances like monochlorobimane that block the crosslinking of the thiols. Cyclosporine A can be replaced by its nonimmunosuppressor analogue, N-methyl Val-4-cyclosporine A, which shows that its inhibitory effect on PT and nuclear apoptosis is independent from its calcineurine activity. These results suggest the implication of the PT pores opening in the regulation of apoptosis induced via the mitochondria.

Nuclei and mitochondria have been purified from hybridomas of T cells transfected by $b c l-2$ to study how Bcl-2 suppress apoptosis in in vitro experiments (Zamzami et al., 1996b). Upon treatment with atractyloside, in contrast to mitochondria purified from control cells, mitochondria purified from cells transfected by $b c l-2$ do not provoke nuclear apoptosis. On the contrary, nuclei purified from cells transfected by $b c l-2$ show a condensation of the chromatin and a fragmentation of the DNA when they are confronted to control mitochondria treated with atractyloside. Furthermore, $b c l-2$ inhibits the induction of permeability transition by agents such as atractyloside, oxidants and protonophores. These results show that, even if Bcl-2 intervenes also during latter apoptotic events (Guénal et al., 1997; Marton et al., 1997) and on $\Delta \Psi_{\mathrm{m}}$ loss induced by other mechanisms (Shimizu et al., 1998), at least a part of its activity is exerted by acting on the mitochondrial permeability transition (Decaudin et al., 1997). Moreover, the structure of a protein of the Bcl-2 family $\left(\mathrm{Bcl}-\mathrm{x}_{\mathrm{L}}\right)$ has been established (Muchmore et al., 1996). It recalls that of bacterial toxins, especially the diphtheria toxin, that form a $\mathrm{pH}$-sensitive 
transmembrane channel. Furthermore, the pro-apoptotic Bax protein can form channels (Antonsson et al., 1997), as reported also for the anti-apoptotic proteins Bcl-x (Minn et al., 1997) and Bcl-2 (Schendel et al., 1997). However, the intrinsic properties of Bax and those of $\mathrm{Bcl}-\mathrm{x}_{\mathrm{L}}$ and $\mathrm{Bcl}-2$ reveal differences. The channel forming activity of Bcl- $\mathrm{x}_{\mathrm{L}}$ and $\mathrm{Bcl}-2$ is observed at highly acidic $\mathrm{pH}$ while $\mathrm{Bax}$ form channel in a wide range of $\mathrm{pH}$ including at $\mathrm{pH}=7$, those found in cells. Furthermore, Bcl-2 can block the pore-forming activity of Bax. Indeed, recent results suggest that Bax might produces cell death by inducing PT (Pastorino et al., 1998). Bcl-2 might counteract this effect of Bax on mitochondrial membranes (Gross et al., 1998).

\section{MITOCHONDRIA OF CELLS UNDERGOING APOPTOSIS RELEASE PRO-APOPTOTIC FACTORS}

\section{Mitochondria undergoing permeability transition liberate AIF factor.}

The experiments described above showed that mitochondria from apoptotic cells can effectively control nuclear apoptosis and suggest the involvement of mitochondria derived products in the apoptotic cascade. Acellular experiments have permitted to show that mitochondria contain a preformed approximately $50-\mathrm{kD}$ protein which is released upon PT pores opening and which causes isolated nuclei to undergo apoptotic changes such as chromatin condensation and internucleosomal DNA fragmentation (Fig. 1). This apoptosis-inducing factor (AIF) derived from the mitochondria is a protease (or a protease-activating protein) which is blocked by the general caspase inhibitor Z-VAD and is capable to activate purified procaspase-3 (Susin et al., 1996). As expected, when preventing mitochondrial permeability transition, Bcl-2 overexpressed in the outer mitochondrial membrane also 
impedes the release of AIF from isolated mitochondria. In contrast, Bcl-2 does not affect the formation of AIF, which is contained in comparable quantities in control mitochondria and in mitochondria from Bcl-2-hyperexpressing cells. Furthermore, the presence of Bcl-2 in the nuclear membrane does not interfere with the action of AIF on the nucleus, nor does Bcl-2 overexpression protect cells against AIF. It thus appears that Bcl-2 prevents apoptosis by favoring the retention of an apoptogenic protein in mitochondria (Susin et al., 1996).

\section{Cytochrome $\mathrm{c}$ is released by mitochondria during apoptosis}

Another mitochondrial killer component has been demonstrated through the role of cytochrome $\mathrm{c}$ in PCD. Indeed, translocation of cytochrome c from mitochondria to cytosol has been shown to be a crucial step in the activation of the PCD machinery in various death models, including Fas-, UV, staurosporine or etoposide-treated mammalian cells, in a cell-free system using Xenopus egg extracts or dATP-primed cytosols of growing cells (Kluck et al., 1997a; Krippner et al., 1996; Liu et al., 1996; Yang et al., 1997). Furthermore, direct microinjection of cytochrome $\mathrm{c}$ into the cytosol can induce apoptosis in various cell types (Li et al., 1997a; Zhivotovsky et al., 1998). Cytochrome $\mathrm{c}$ is an essential component of the mitochondrial respiratory chain: it accepts an electron from cytochrome c reductase and passes it on to cytochrome c oxidase. It is a soluble protein that is located in the intermembrane space and is loosely attached to the surface of the inner mitochondrial membrane. Cytochrome $\mathrm{c}$ is translated on cytoplasmic ribosomes as apocytochrome $\mathrm{c}$ and follows a unique pathway into mitochondria that does not require the signal sequence, electrochemical potential and general protein translocation machinery (Mayer et al., 1995). The apoprotein, on entry into the intermembrane space, gains an heme group, to become the fully folded holocytochrome c. This globular, positively 
charged protein can no longer pass through the outer mitochondrial membrane and is thought to become electrostatically attached to the inner membrane.

Upon its release into the cytoplasm during the initiation of apoptosis, cytochrome $\mathrm{c}$ promotes the assembly of a multiprotein complex, the apoptosome, that induces proteolytic processing and activation of executive caspases (Li et al., 1997b). Biochemical studies have shown that, besides cytochrome c, caspase-9, Apaf-1 and (d)ATP constituted the activating components of this complex. Apaf-1 and caspase-9 interact via their CARD domains, an association that requires dATP and cytochrome c. Binding of dATP and cytochrome $\mathrm{c}$ to Apaf-1 likely alters it's conformation and renders its CARD domain more available to caspase-9. Once bound to caspase-9, Apaf-1 triggers caspase-9 proteolytic self-activation; caspase-9 subsequently proteolyses and activates caspase-3.

Many data suggested that the pro-survival Bcl-2 proteins prevent cell death acting upstream the release of cytochrome c. Overexpresssion of Bcl-2 or Bcl- $\mathrm{x}_{\mathrm{L}}$ in cells blocks the release of cytochrome $\mathrm{c}$ and aborts the apoptotic response triggered by a wide variety of killing signals (Bossy-Wetzel et al., 1998; Kharbanda et al., 1997; Van der Heiden et al., 1997; Yang et al., 1997). On the contrary, caspases inhibitors have no effect on this process. Similarly, addition of recombinant Bcl-2 to Xenopus egg extracts containing mitochondria slows down the release of cytochrome $\mathrm{c}$ from these mitochondria and inhibits nuclear apoptosis observed in this cell-free system (Kluck et al., 1997a). Moreover, co-immunoprecipitation studies have shown that $\mathrm{Bcl}-\mathrm{x}_{\mathrm{L}}$ can bind cytochrome $\mathrm{c}$ and may thereby act to sequester it in the mitochondria (Kharbanda et al., 1997). Bcl-xs , a pro-apoptotic derivative of $\mathrm{Bcl}-\mathrm{x}_{\mathrm{L}}$, was found to prevent the formation of the $\mathrm{Bcl}-\mathrm{x}_{\mathrm{L}}$-cytochrome $\mathrm{c}$ complex. In contrast, overexpression of the pro-apoptotic Bcl-2 family member Bax in cells stimulates both the release of cytochrome $\mathrm{c}$ and 
apoptosis. By using isolated mitochondria and recombinant Bax, it was shown that Bax can directly induce cytochrome c release from mitochondria. Similarly, recent reports show that Bid, a $\mathrm{BH} 3$ domain-containing proapoptotic Bcl-2 family member, induces cytochrome c release and apoptosis after its caspase-8-dependent cleavage and subsequent translocation onto mitochondria (Li et al., 1998; Luo et al., 1998). Even though, altogether, these results provide evidence that $\mathrm{Bcl}-2$ family members can modulate cell death process by directly controlling the availability of cytochrome $\mathrm{c}$ in the cytosol (Fig.1), it must underlined that pro-survival actors, as Bcl-2/ Bcl- $\mathrm{x}_{\mathrm{L}}$, may also act downstream of cytochrome $\mathrm{c}$ to prevent caspase activation under certain circumstances (see below) (Rosse et al., 1998; Zhivotovsky et al., 1998).

Although efflux of cytochrome $\mathrm{c}$ from mitochondria appears to be a crucial step in the killing cascade initiated by a wide range of apoptogenic stimuli, it must be underlined that this event is not an universal requirement for death signal transduction. Indeed, on the one hand, apoptosis can occur in the absence of detectable cytochrome c release (Chauhan et al., 1997; Tang et al., 1998) and, on the other hand, under certain circumstances, cytochrome c release is not sufficient to promote cell death (Li et al., 1997a). Moreover, it was reported that efflux of cytochrome c could constitutes only a later event of the cell death, in other words, a side effect of the terminal dismantelment of the cell (Adachi et al., 1998; Krippner et al., 1996). However, in this Fasmediated apoptosis model, an inactivation of cytochrome c, correlated to the inhibition of mitochondrial respiration at the cytochrome c level, constitutes an very early causal event in the apoptotic program. It was suggested that inactivation of cytochrome $\mathrm{c}$ is associated to its release from the outer surface of the inner mitochondrial membrane where normally it functions as a shuttle connecting respiratory chain energy transducers (Skulachev, 1998). More intriguing, the authors suggest that efflux of cytochrome $\mathrm{c}$ which had been 
associated with early events of apoptosis could be, in some instances, the result of a methodological artifact (Adachi et al., 1998). Indeed, most studies are based on subcellular fractionations, i.e.: after cell disruption, centrifugation allows to separate soluble cytosolic elements in the supernatant from heavy membranes, including mitochondria, included in the pellet. In this approach, the in vivo cytochrome $\mathrm{c}$ redistribution is inferred from its appearance into the cytosolic fraction during the in vitro procedure. In fact, this method could be more properly considered as a measure of cytochrome c extractability from mitochondria rather than as a exact view of its in situ localization. For instance, some minor alterations of the outer mitochondrial membrane c could be compatible with a mitochondrial localization of cytochrome $\mathrm{c}$ in the cell and its outflow from mitochondria as fractionation provoked breakdown of the fragilized outer membrane. However, these considerations refute neither the early occurrence of cytochrome c release in various apoptotic models as observed by in situ immunolocalization and nor its crucial role in the apoptotic program, ascertained by direct microinjection of cytochrome $\mathrm{c}$ in the cytosol. They must be correlated to the evidenced existence of alternative pathways, i.e. cytochrome $\mathrm{c}$ independent, in the transduction of apoptogenic stimuli (Chauhan et al., 1997; Li et al., 1997a; Tang et al., 1998).

\section{The cytochrome c pathway is distinct from that of AIF}

The above described AIF could be a key regulator of such a cytochrome c-independent pathway inasmuch as these two mitochondrial components seem involved in distinct signaling route. Indeed, while AIF release occurs after the PT-associated mitochondrial depolarization, several reports indicates that cytochrome c release is dissociable from PT (BossyWetzel et al., 1998; Jurgensmeier et al., 1998; Kluck et al., 1997a; Li et al., 1998; Van der Heiden et al., 1997; Yang et al., 1997). Furthermore, cytosolic 
cytochrome c requires additional cytosolic factors to promote apoptotic changes, via the activation of caspase-3, whereas AIF, once released from mitochondria, directly induces nuclear apoptosis without cytosol. Beyond their differences, these two "execution caspase" activating pathways illustrate the sophistication and the apparent molecular redundancy which characterize the mammalian cell death. They may correspond to alternative and independent links between death-triggering stimuli and the execution machinery or, in contrast, they may work together to induce complete PCD (Golstein, 1997).

\section{Bcl-2 family proteins dock various proteins to the mitochondria}

Even though, increasing reports provide evidence that Bcl-2 family members can modulate cell death process by directly controlling the availability of cytochrome $\mathrm{c}$ in the cytosol, it must underlined that pro-survival actors, as $\mathrm{Bcl}-2 / \mathrm{Bcl}-\mathrm{x}_{\mathrm{L}}$, may also act downstream of cytochrome $\mathrm{c}$ to prevent caspase activation under certain circumstances (Rosse et al., 1998; Zhivotovsky et al., 1998). Moreover, effects of Bcl-2s cannot be reduced merely to models that envision $\mathrm{Bcl}-2 \mathrm{~s}$ as regulators of killing caspase activation, inasmuch as Bcl-2 can also block caspase-independent cell deaths such as oxidant and hypoxia-induced necrosis, or Bax-induced yeast killing (Jürgensmeier et al., 1997; Manon et al., 1997). The ability of Bcl-2 to bind (at least in two hybrid or co-immunoprecipitation experiments) and to dock several cellular proteins that do not belong to the Bcl-2 related proteins family, can provide a clue to understand how the Bcl-2 family governs PCD.

First, Bcl-2 has been found to interact with Nip1, Nip2, and Nip3, the function of which is unknown (Boyd et al., 1994), the GTPase R-ras p23 (Fernandez and Bischoff, 1993), Raf-1 (Ali et al., 1997; Wang et al., 1994), BAG-1 (Takayama et al., 1995), the cellular prion protein (PrP) (Kurschner and Morgan, 1995), the p53 binding-protein p53-BP2 (Naumovski and Cleary, 
1996), the protein phosphatase calcineurin (Shibasaki et al., 1997) and the mitochondrial membrane protein carnitine palmitoyltransferase I (Paumen et al., 1997). At least some of these interactions could reflect the ability of Bcl-2 to relocalize cellular proteins to mitochondrial membranes.

Bcl-2 binds to BAG-1 (Takayama et al., 1995) that can also interact with Raf-1 (Wang et al., 1996b). Active Raf-1 fused with targeting sequences from an outer mitochondrial membrane protein protect cells from apoptosis and phosphorylate BAD, a proapoptotic Bcl-2 homologue (Wang et al., 1996a). Furthermore, plasma membrane-targeted Raf-1 did not protect from apoptosis and resulted in phosphorylation of ERK-1 and ERK-2 while Raf-1 improved Bcl-2-mediated resistance to apoptosis. Bcl-2 can therefore target Raf-1 to mitochondrial membranes, allowing this kinase to phosphorylate BAD. However, the link between Raf-1 and the mitochondrial changes occurring during apoptosis are not yet known and bcl-2 does not always require c-raf-1 kinase activity and an associated mitogen-activated protein kinase signaling pathway for its survival function (Olivier et al., 1997).

Second, in accord with $C$. elegans genetics, biochemical evidences show that the pro-survival $\mathrm{Bcl}-2$ family proteins may function by directly inhibiting the activation of killing caspases. It was initially shown that binding of CED-9 to CED-4 prevents CED-4 from inducing proteolytic processing and activation of CED-3 (Chinnaiyan et al., 1997b; Wu et al., 1997b). The CED-9 protein, like the mammalian Bcl-2 related proteins, is localized to intracellular membranes and the perinuclear region, whereas CED-4 was distributed in the cytosol. Expression of CED-9, but not a mutant lacking the carboxy-terminal hydrophobic domain, targeted CED-4 from the cytosol to intracellular membranes in mammalian cells (Wu et al., 1997b). A similar mechanism exists in mammalian cells as first suggested by the ability of Bcl- $x_{L}$ to interact with and inhibit the function of CED-4 (Chinnaiyan et al., 1997b). An ternary 


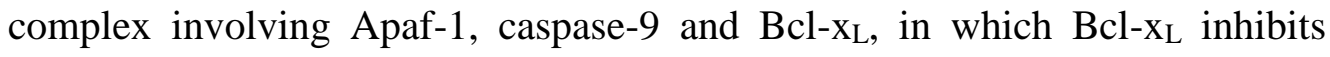
Apaf-1-mediated maturation of caspase-9, was found to be present in mammalian cells (Hu et al., 1998; Pan et al., 1998). The figure 2 illustrates that pro-apoptotic relatives like Bik, Bak and Bax can promote cell death by disrupting interaction between Bcl- $\mathrm{x}_{\mathrm{L}}$ and Apaf-1 (Chinnaiyan et al., 1997b; Pan et al., 1998). Such data explain how pro-survival actors, as Bcl-2/ Bcl- $\mathrm{x}_{\mathrm{L}}$, may also act downstream of cytochrome $\mathrm{c}$ to prevent caspase activation under certain circumstances. For instance, overexpression of $\mathrm{Bcl}-2$ and $\mathrm{Bcl}-\mathrm{X}_{\mathrm{L}}$ inhibits apoptosis induced by direct injection of cytochrome $\mathrm{c}$ in cytosol ( $\mathrm{Li}$ et al., 1997a; Zhivotovsky et al., 1998). Similarly, Bcl-2 delays Bax-induced caspase activation and cell death even when cytochrome $\mathrm{c}$ is already in the cytosol (Rosse et al., 1998). However, it must underlined that today there is no evidence concerning a physical interaction of $\mathrm{Bcl}-2$ with apoptosome complex. Lastly, there is some evidence that binding of pro-survival proteins to the Apaf-1/caspase-9 complex alters its location in cells, dragging it from the cytosol to the intracellular membranes where $\mathrm{Bcl}-2 \mathrm{~s}$ often reside (Chinnaiyan et al., 1997b; Wu et al., 1997b). In murine thymocytes, Bcl-2 is exclusively membrane-bound, whereas $\mathrm{Bcl}-\mathrm{x}_{\mathrm{L}}$ is present in both soluble and membrane-bound forms and Bax is present predominantly in the cytosol. Induction of apoptosis by dexamethasone or gamma-irradiation shifts the subcellular locations of $\mathrm{Bax}$ and $\mathrm{Bcl}-\mathrm{x}_{\mathrm{L}}$ from soluble to membrane-bound forms. Inhibition of apoptosis with cycloheximide inhibits the movement of Bax and Bcl- $\mathrm{x}_{\mathrm{L}}$ from the cytosol into intracellular membranes (Hsu et al., 1997). Since Bax and Bik can disrupt the association between CED-9 (or Bcl-xL) and CED-4 (Chinnaiyan et al., 1997b), it is tempting to speculate that Bcl- $\mathrm{x}_{\mathrm{L}}$ and possibly other members of the Bcl-2 protein family inhibit apoptosis by maintaining the procaspases/Apaf-1 complexes associated to 
mitochondrial membranes and that Bax and Bik by dissociating the complexes permit the activation of procaspases.

\section{What is the mechanism involved in cytoplasmic release of mitochondrial apoptogenic factors?}

The mechanism by which AIF and cytochrome $\mathrm{c}$ are released from mitochondria is largely unknown. Although apoptosis can occur in the absence of detectable cytochrome c release (Chauhan et al., 1997; Tang et al., 1998), efflux of cytochrome $\mathrm{c}$ from mitochondria appears to be a critical coordinating step in the killing program towards which converge the multiple signaling pathways and beyond which are initiated the entire panel of apoptotic features, pro-caspase 3 expressing cells being then irreversibly committed to die ( $\mathrm{Li}$ et al., 1997a). With this perspective, the possible mechanisms involved in activation of this central control may be envisaged from data concerning mediators of the death signal transduction cascades.

For instance, the release of cytochrome $\mathrm{c}$ might result from oxidative imbalance, an upstream event in the apoptotic transduction cascade (see below). This phenomena might lead to the alteration of some redox sensitive crucial regulatory elements of the outer mitochondrial membrane permeability, e.g. by a shift of the redox state of some sulfhydryl groups to a more inactivating oxidized state.

Another possibility comes from the ability of caspases to promote release intermembrane proteins, including cytochrome $\mathrm{c}$ and AIF, through the outer mitochondrial membrane. These observations suggested that mitochondria carry a caspase substrate that, when cleaved, promotes cytochrome c-release (Mignotte and Vayssière, 1998). Recent reports concerning Fas and TNF- $\alpha$ receptor signaling could provide insight into how caspase induce cytochrome c efflux. Previously, it had been established that 
activation of caspases, predominantly the caspase-8, constitutes an early step in these apoptotic pathways (Nagata, 1997), and that inhibition of these proteases prevents both the release of cytochrome $\mathrm{c}$ from mitochondria and the execution of the cell death program (Schulze-Osthoff et al., 1998; Van der Heiden et al., 1997). Recently, it has been shown that caspase-8, activated by cell surface death receptors such as TNF and Fas, cleaves Bid, a death agonist of the Bcl-2 family, which in turn transduces the apoptotic signal from the cell surface to mitochondria ( $\mathrm{Li}$ et al., 1998; Luo et al., 1998). Thus, while fulllength Bid is localized in cytosol, the C-terminal part caspase-8-truncated BID translocates to mitochondria and then induces cytochrome c release and the downstream caspase-dependent apoptotic program.

These results point to a model where mitochondria might act as apoptotic amplifiers, fostering a positive feedback loop between cytochrome c-efflux and caspase activation. Any event that primes the loop will initiate the vicious "circle of death", leading to large-scale caspase activation and apoptotic cell death. However, this model does not prevail in all systems as, in numerous PCD, caspase inhibitors have no effect on the loss of cytochrome c (Bossy-Wetzel et al., 1998; Kluck et al., 1997a; Kluck et al., 1997b).

Alternatively, opening of PT pores, which is a common event of apoptosis, might be involved in AIF and cytochrome c outflow (Skulachev, 1998). However,. PT pores, which are thought to connect the mitochondrial matrix to the cytosol, within the contact sites between inner and outer mitochondrial membranes (Beutner et al., 1996) are only permeable to small compounds (molecular mass $<1500 \mathrm{Da}$ ) and therefore are probably not the structure directly responsible for the efflux of these intermembrane space apoptogenic proteins. Nevertheless, opening of the PT pore could be a first step of a cascade of events causing an increase in matrix volume and 
subsequently a mechanic disruption of the outer membrane. Recent results show that this scenario is possible at least in vitro (Petit et al., 1998; Scarlett and Murphy, 1997; Van der Heiden et al., 1997).

Last, the pore-forming properties of Bax and other related proteins might suggest that they directly modulate the permeability of the outer mitochondrial membrane. Indeed, other studies have shown that Bax can induce cytochrome $\mathrm{c}$ release from mitochondria and caspase processing and activation (Jurgensmeier et al., 1998). These events are sensitive to Bcl- $\mathrm{x}_{\mathrm{L}}$ but caspase inhibitors have no effect on release of cytochrome c from mitochondria (Gross et al., 1998; Xiang et al., 1996) although they prevent the subsequent activation of caspases in cytosolic extracts. Unlike $\mathrm{Ca}^{++}$, Bax did not induce PT and swelling of mitochondria in vitro in this system. These findings imply that Bax could uses an alternative mechanism for triggering release of cytochrome $\mathrm{c}$ from mitochondria. may be through to the action of specific pores in the outer membrane.

\section{MITOCHONDRIAL ROS AND APOPTOSIS SIGNALLING}

\section{ROS as mediators of PCD}

First evidence suggesting the involvement of mitochondria in cell death arose from the study of the TNF- $\alpha$-induced cytotoxicity (Lancaster et al., 1989; Schulze-Osthoff et al., 1992). Indeed, an alteration of the mitochondrial function was associated with the early phases of the cell death and was defined as a crucial step of the process. The observed inhibition of the mitochondrial respiratory chain was assumed to result in the over production 
of Reactive Oxygen Species (ROS) which would act as mediators of the death signaling pathway (Schulze-Osthoff et al., 1993).

ROS, such as superoxide anion, hydrogen, organic peroxides and radicals, are generated by all aerobic cells as byproducts of a number of metabolite reactions and in response to various stimuli (Fridovich, 1978). Mitochondria are believed to be a major site of ROS production: superoxide radical is produced by a single electron transfer to molecular oxygen at the level of the respiratory chain, mainly at the ubiquinone site in complex III. However, endoplasmic reticulum and nuclear membranes also contain $\mathrm{e}^{-}$ transport chains that can lose $\mathrm{e}^{-}$and generate superoxide radical. Some fatty acid metabolites, such as those derived from arachidonic acid by the lipoxygenase pathway, are also ROS. However, ROS play a role in physiological systems : they were shown to be responsible for the inducible expression of genes associated with inflammatory and immune responses. Current evidence indicates that different stimuli use ROS as signaling messengers to activate transcription factors, such as AP-1 and NF- $\kappa \mathrm{B}$, and induce gene expression (Pinkus et al., 1996).

The ability of oxidative stress, which is an excessive production of ROS, to provoke necrotic cell death as a result of massive cellular damages associated to lipid peroxidation and alterations of proteins and nucleic acids, is well documented for a long time (Halliwell and Gutteridge, 1989). The highly reactive hydroxyl radical $(\cdot \mathrm{OH})$, by-product of superoxide anion or hydrogen peroxide, is assumed to be directly responsible for most of the oxidative damages leading to the non-physiological necrosis (Halliwell and Gutteridge, 1990). To prevent oxidative damage, mammalian cells have developed a complex antioxidant defense system that includes nonenzymatic antioxidants (e.g. glutathione, thioredoxine) as well as enzymatic activities (e.g. catalase, superoxide dismutase (SOD)) (Sies, 1991). In this point of view, aerobic cells 
appear as being under a continual "oxidative siege", their survival depending on a balance between ROS and antioxidants. On the other hand, the possible implication of ROS as signaling molecules in more physiological deaths such as PCD is an emerging concept. Thus, since the initial observation outlining the contribution of ROS to the TNF- $\alpha$-induced cytotoxicity, there is mounting evidence that these compounds may be central in the cell death transduction pathways. Indeed, several observations suggest that ROS might mediate PCD: 1) the addition of ROS or the depletion of endogenous antioxidants can promote cell death (Guénal et al., 1997; Kane et al., 1993; Lennon et al., 1991; Ratan et al., 1994; Sato et al., 1995), 2) PCD can sometimes be delayed or inhibited by antioxidants (Greenlund et al., 1995; Mayer and Noble, 1994; Mehlen et al., 1996; Sandstrom and Buttke, 1993; Wong et al., 1989) and 3) increases in intracellular ROS are sometimes associated with PCD (Martin and Cotter, 1991; Quillet-Mary et al., 1997; Uckun et al., 1992). Moreover, it was shown that Bcl-2 may act in an antioxidant pathway to block a putative ROSmediated step in the cascade of events required for PCD (see below). So, in addition to their role in TNF- $\alpha$-induced killing, the contribution of ROS to the activation of the execution machinery was extended to PCD triggered by a wide range of influences including UV light, ionizing irradiation, anthracyclines, ceramides, glucocorticoids or survival-factor withdrawal (see [106]. Moreover some data raise the possibility that ROS are also required for the execution of the death program (Kroemer et al., 1995). However, they must be cautiously considered inasmuch as, in the majority of these systems, it is difficult to ascertain that the observed ROS accumulation corresponds to a causal effect and is not a side effect of the other changes accompanying the killing process (Cai and Jones, 1998). Moreover, in these cases, ROS increase most often arises during the later stage of the death program, i.e. during the destruction phase when the cell is broken down, and may be associated with a 
necrotic type terminal degradation of the cell. Exogenous sources of ROS such as hydrogen peroxide can induce PCD or necrosis depending upon the dose added (Guénal et al., 1997). So a burst in ROS, in response to a dramatic perturbation of the physiology of the dying cell, could convert the late PCD steps into necrotic death. Therefore, it appears that at any moment the level of intracellular ROS can determine the fate of the cell: low levels of ROS can induce PCD while accumulation of high levels promotes necrosis or can lead PCD-committed cells toward necrotic-like destruction.

\section{PCD-mediating ROS are produced by mitochondria}

The nature of the ROS involved in PCD is a conflicting question that will allow us to return to the central subject of this review, i.e. the role of mitochondria in PCD. Indeed, two opposite models have emerged concerning the source of signaling ROS, in relation with the variety of metabolic reactions and intracellular sites which can generate ROS (see above) (Jacobson, 1996). While most investigators believe that oxidants are produced by electron chain transport, some data seem to moderate this point of view. Fatty acid metabolites, such as those produced from arachidonic acid by the lipoxygenase pathway, may be better mediators of PCD (O'Donnell et al., 1995). On the one hand, it is argued that these molecules harbor a more specific reactivity than superoxide anion and its by-products, this biological specificity being assumed necessary for a signaling role in PCD transduction pathways. On the other hand, it was shown that exogenous fatty acid metabolites can promote PCD and that, in some cases, their increased production was associated with cell death. It must be underlined that such a situation is limited to systems where the death signal result is mediated by surface receptors. Nevertheless, these considerations do not refute the compelling evidence of the involvement of electron transport chain-produced 
ROS in cell death signaling. It appears more reasonable to consider that, depending upon the cell death stimulus and the cell model, these two types of ROS can mediate PCD or even both contribute to the activation of the execution machinery as suggested by studies of TNF- $\alpha$-induced PCD.

Where are localized the electron transport chains that produce cell death signaling ROS such as hydrogen peroxide? The question must address distinct intracellular compartments as reticulum endoplasmic, nuclear layer and especially mitochondria. The more convincing responses have arisen from indirect studies measuring the consequences of an alteration of the electron transport chain on the PCD process. In this way, it was established that both ROS accumulation and PCD process require the presence of a functional mitochondrial respiratory chain in most ROS-dependent cell death systems (Higuchi et al., 1997; Quillet-Mary et al., 1997; Schulze-Osthoff et al., 1993; Sidoti-de Fraisse et al., 1998). Indeed, it was shown that an upstream inhibition, with chemical compounds acting on complex I (Quillet-Mary et al., 1997; Schulze-Osthoff et al., 1992), or an elimination of the electron transfer chain (Higuchi et al., 1997; Schulze-Osthoff et al., 1993; Sidoti-de Fraisse et al., 1998), by depletion of the mtDNA, prevent ROS accumulation and consequently protect cells against PCD. Another indirect argument is provided by the scavenger role of mitochondrial glutathione in the regulation of ROSmediated PCD (Goossens et al., 1995). The ubiquinone site in complex III appears as the major site of mitochondrial ROS production as this site catalyzes the conversion of molecular oxygen to superoxide anion which can lead to the formation of other potent ROS such as hydrogen peroxide and hydrogen radicals. Such a model is supported by the observed potentiation of cell death processes in ROS-dependent PCD when electron flow was inhibited distal to the ubiquinone pool. 


\section{Mechanisms of ROS signaling}

The involvement of mitochondrial ROS in some cell death transduction pathways next leads to the fundamental questions concerning, on the one hand, the causal event of the increased ROS generation and, on the other hand, the molecular mechanisms underlying the ROS signaling. Two viewpoints must first be considered to address the question of the origin of ROS accumulation, which can indeed result from an increased production or from a reduced scavenging by the cellular detoxifying systems. Much of the available data converge to the hypothesis that ROS increases are the consequence of an impairment of the mitochondrial respiratory chain (Cai and Jones, 1998; Degli Esposti and McLennan, 1998; France-Lanord et al., 1997; Gudz et al., 1997; Quillet-Mary et al., 1997; Schulze-Osthoff et al., 1992). In agreement with the above considerations, the observed alterations are distal to the ubiquinone site of the complex III, but the origin of these electron flow disturbances are not clear. The only strong evidence comes from the study of ceramide-induced PCD, in which an increased $\mathrm{H}_{2} \mathrm{O}_{2}$ production was linked to mitochondrial $\mathrm{Ca}^{2+}$ homeostasis perturbation as inhibition of the mitochondrial $\mathrm{Ca}^{2+}$ uptake was shown to abolish both ROS accumulation and cell death. However, the recently observed shift of cytochrome c from mitochondria to cytosol in the early phases of many PCD (see above) could provide a clue to resolve this question (Kluck et al., 1997a; Liu et al., 1996; Yang et al., 1997). Indeed, the release of cytochrome c must lead to a breakdown of the mitochondrial electron flow downstream of the ubiquinone site which in turn would result in an increased generation of ROS. Such a model is supported by the described correlation between loss of cytochrome c activity and respiratory failure in a Fas-induced PCD model (Krippner et al., 1996) and by the study of mitochondria isolated from apoptotic cells which shows a superoxide production due to a switch from the normal 4-electron reduction of $\mathrm{O} 2$ to a 1- 
electron reduction when cytochrome $\mathrm{c}$ is released from mitochondria. (Cai and Jones, 1998).

Beside the question of the process of mitochondrial ROS accumulation, arises the problematic concerning the targets of these compounds or more precisely: how can they mediate PCD? Two models can be proposed to approach this conflicting and not well documented subject. The first model assumes that ROS themselves are signaling molecules which activate some crucial components of the PCD machinery. Conversely, the alternative proposition suggests that ROS can act indirectly by modifying the cellular redox potential, which would regulate some key regulatory proteins involved in PCD. Several lines of evidence agree with an explanation based on indirectly mediated action. First, unlike fatty acid metabolites which harbor specific reactivity and are known to mediate particular signals from surface receptors, mitochondrial ROS are characterized by a lack of biological specificity or even an extreme reactivity, as for the hydroxyl radical: these are all features contrary to the requirements of a specific signaling role (Jacobson, 1996). In this way, a direct influence of ROS on PCD process would be correlated to a general damaging effect on cellular structures resulting in necrotic cell death, or perhaps to a more limited action on mitochondria, their site of production, which in turn could activate some mitochondria-dependent downstream cascades leading to PCD. Secondly, despite the compelling evidence of the role of mitochondrial ROS in PCD signaling pathways, it has been assumed that they do not represent a general mediator of cell death, as suggested by the ability of some PCD to occur in very low oxygen environments (Jacobson and Raff, 1995; Shimizu et al., 1995). However, ROS might be produced in such conditions (Degli Esposti and McLennan, 1998). Another alternative explanation would be to consider that the major effect of an increased ROS production is the subsequent imbalance of intracellular 
redox status, i.e. an enhancement of the cellular oxidative tonus, and that in fact the oxidative stress is the central common effector of PCD. Hence, ROS accumulation would only be one way which leads in some PCD to an oxidative status. Anti-Fas/APO-1 antibody or IL-3 withdrawal-induced PCD represent good illustrations of this model (Bojes et al., 1997; van den Dobbelsteen et al., 1996). Indeed, no ROS accumulation can be measured in these two systems and anareobic cultured cells deprived of IL-3 still undergo PCD (Schulze-Osthoff et al., 1994; Shimizu et al., 1995). However, an oxidative stress can be shown in these models as a depletion of glutathione (GSH), a non-enzymatic cellular antioxidant, as a result of a rapid and specific efflux of glutathione, an event that takes place at the very beginning of the apoptotic process (Bojes et al., 1997; van den Dobbelsteen et al., 1996). Moreover, it has been shown that Bcl-2 can protect cells from PCD by shifting the cellular redox potential to a more reduced state (see below). However, the observation that oxidation of thiols other than glutathione can mediate induction of PCD suggest that the intracellular thiol redox status would be the real key factor of the cell death signaling pathways (Kane et al., 1993; Marchetti et al., 1997; Mirkovic et al., 1997; Sato et al., 1995). In this model, the redox state of glutathione or other cellular antioxidants such as thioredoxine, would be in equilibrium with that of thiols resident in some redox sensitive crucial components of the execution machinery (Kroemer et al., 1997). Where does ROS fit this thiol hypothesis? In this putative model, an increased production of mitochondrial ROS would result, either by a direct modification of the thiols or indirectly via a depletion of the intracellular antioxidant pool, in a shift of the redox state of the sensor $\mathrm{SH}$ groups to a more oxidized state. The nature of the ROS and the level of the intracellular antioxidant defenses would determine in which way regulatory components are activated to commit cells to PCD. In an hypothetical model (figure 3), 
mitochondrial ROS modify the membrane permeability leading to the release of pro-apoptotic factors and/or activate directly executing caspases.

Several lines of evidence support the idea that Bcl-2 acts in an antioxidant pathway to suppress apoptosis. Yeast mutants lacking superoxide dismutase were partially rescued by expression of Bcl-2 (Kane et al., 1993; Longo et al., 1997). Following an apoptotic signal, overexpression of Bcl-2 suppressed lipid peroxidation completely (Hockenbery et al., 1993). Bcl-2 deficient mice turn gray with the second hair follicle cycle, implicating possibly a defect in redox-regulated melanin synthesis (Veis et al., 1993). Bcl2 can protect neural cells from delayed death resulting from chemical hypoxia and reenergization, and may do so by an antioxidant mechanism (Myers et al., 1995) (reviewed in (Korsmeyer et al., 1995)).

The way by which Bcl-2 protects from ROS remains unclear. In some systems, Bcl-2 appears to influence the generation of oxygen free radicals (Kane et al., 1993) while in other cases it does not affect ROS production but does prevent oxidative damage to cellular constituents (Hockenbery et al., 1993; Tyurina et al., 1997). Alternatively, since superoxide is produced by mitochondria from apoptotic cells due to a switch from the normal 4-electron reduction of $\mathrm{O}_{2}$ to a 1-electron reduction, the block of cytochrome c release could provides a mechanism for the apparent antioxidant function of Bcl-2 (Cai and Jones, 1998).

Several authors have studied the effect of Bcl-2 family proteins on cellular redox potential. Activities of antioxidant enzymes and levels of glutathione and pyridine nucleotides have been measured in pheochromocytoma PC12 and the hypothalamic GnRH cell line GT1-7 cells transfected with bcl-2 (Ellerby et al., 1996). Both cell lines overexpressing bcl-2 had elevated total glutathione levels when compared with control transfectants. The ratios of oxidized glutathione to total glutathione in PC12 
and GT1-7 cells overexpressing $b c l-2$ were significantly reduced. In addition, the NAD+/NADH ratio of $b c l-2$-expressing PC12 and GT1-7 cells was two- to threefold less than that of control cell lines while they had approximately the same level of catalase, superoxide dismutase, glutathione peroxidase and glutathione reductase activities as control cells. These results indicate that the overexpression of $b c l-2$ shifts the cellular redox potential to a more reduced state, without consistently affecting the major cellular antioxidant enzymes. Furthermore, depleting cellular thiols reversed the resistance to radiation in Bcl-2 expressing lymphoma cell lines (Mirkovic et al., 1997).

The ability of bax and $b c l-x_{L}$ to affect GSH was assessed in interleukin (IL)-3-dependent murine prolymphocytic FL5.12 cells (Bojes et al., 1997). Overall levels of GSH increased in $b c l-x_{L}$ transfectants while, in cells overexpressing bax, GSH was reduced by approximately $36 \%$. There were no consistent differences between these cell lines in the activities of superoxide dismutase, catalase, glutathione peroxidase or glutathione reductase. Following IL-3 withdrawal-induced apoptosis, control cells and bax transfectants exhibit a rapid loss of intracellular GSH that seemed to occur due to a translocation out of the cell. Cells overexpressing $b c l-x_{L}$ did not lose significant amounts of GSH upon withdrawal of IL-3, and no apoptosis was evident. These results suggest a possible role for GSH in the mechanism by which Bcl- $x_{\mathrm{L}}$ prevents cell death.

Thus, both $\mathrm{Bcl}-2$ and $\mathrm{Bcl}-\mathrm{x}_{\mathrm{L}}$ can protect cells from apoptosis by shifting the cellular redox potential to a more reduced state. Assuming that mitochondrial thiols constitute a critical sensor of the cellular redox potential during apoptosis (Marchetti et al., 1997), these effects could be at the mitochondrial level. 


\section{CONCLUSIONS}

In conclusion, mitochondria are involved in the decision of cells to survive or not at several levels. At a first level, mitochondria can contribute to apoptosis signaling, as shown in TNF- $\alpha$ - or ceramide-induced cell death during which increased mitochondrial ROS production appears as an early event of the induction phase. At a second level, mitochondria are involved in the control of the activation of the cell death machinery by docking at their surface, via Bcl-2 family proteins, execution caspases or by sequestering, in the intermembrane space, caspase activators as AIF or cytochrome c.

This recent accumulation of data has also generated a number of new questions. Future works must address the connection between survival signals and mitochondrial functions. The study of Bad regulation, a proapoptotic $\mathrm{Bcl}-2$ member which is supposed to counteract $\mathrm{Bcl}-2$ has provided an example of how survival factors counteract PCD. Indeed, Bad is inactivated by phosphorylation by Akt (Datta et al., 1997; del Peso et al., 1997) and Raf-1 (Wang et al., 1996a), two kinases involved in survival signals transduction. It has been suggested that, in the absence of phosphorylation, Bad induces cell death possibly via the formation of heterodimers with $\mathrm{Bcl}-\mathrm{x}_{\mathrm{L}}$ (or Bcl-2 depending of the cell type) and the concomitant generation of Bax homodimers. Assuming that all mammalian cells constitutively express all the protein components required to execute the death program (Jacobson et al., 1994), these results suggest that Bax (or an other similar pro-apoptotic member of the Bcl-2 family) are ubiquitously expressed and that survival requires their continuous inhibition. Taking into account the mitochondrial membrane localization of these proteins and their pore forming properties, it can be proposed that this kind of regulation operates at the mitochondrial level to control membrane permeability and efflux of AIF and cytochrome c. 
The mechanism allowing for the release of AIF and cytochrome $\mathrm{c}$ needs further investigations. Opening of the PT pore could be just a first step of a cascade of events causing an increase in the permeability of the outer mitochondrial membrane. At present, it remains elusive whether this permeability increase is due to the action of specific pores in the outer membrane and/or to its mechanic disruption secondary to an increase in matrix volume.

Another exciting question to resolve is the occurrence of an apoptosislike phenotype associated with a specific mutation in S. cerevisiae (Madeo et al., 1997). This yeast species seems do not contain caspases or Bcl-2s gene and its cytochrome $\mathrm{c}$ has been shown to be ineffective to induce nuclear apoptosis in acellular assay (Kluck et al., 1997b). These data suggest the existence of yet unknown PCD pathways in which the place and the role of mitochondria remain to be determined. 


\section{REFERENCES}

Adachi, S., Gottlieb, R. A. \& Babior, B. M. (1998) Lack of Release of Cytochrome c from Mitochondria into Cytosol Early in the Course of Fasmediated Apoptosis of Jurkat Cells, J. Biol. Chem. 273, 19892-4.

Adams, J. M. \& Cory, S. (1998) The Bcl-2 protein family: arbiters of cell survival, Science 281, 1322-1326.

Akao, Y., Otsuki, Y., Kataoka, S., Ito, Y. \& Tsujimoto, Y. (1994) Multiple subcellular localization of Bcl-2: detection in nuclear outer membrane, endoplasmic reticulum membrane, and mitochondrial membranes, Cancer Res. 54, 2468-71.

Ali, S. T., Coggins, J. R. \& Jacobs, H. T. (1997) The study of cell death proteins in the outer mitochondrial membrane chemical cross-linking, Biochem. J. 325, 321-324.

Antonsson, B., Conti, F., Ciavatta, A., Montessuit, S., Lewis, S., Martinou, I., Bernasconi, L., Bernard, A., Mermod, J. J., Mazzei, G., Maundrell, K., Gambale, F., Sadoul, R. \& Martinou, J. C. (1997) Inhibition of Bax ChannelForming Activity by Bcl-2, Science 277, 370-372.

Bernardi, P., Vassanelli, S., Veronese, P., Colonna, R., Szabo, I. \& Zoratti, M. (1992) Modulation of the mitochondrial permeability transition pore. Effect of protons and divalent cations, J. Biol. Chem. 267, 2934-9.

Beutner, G., Ruck, A., Riede, B., Welte, W. \& Brdiczka, D. (1996) Complexes between kinases, mitochondrial porin and adenylate translocator in rat brain resemble the permeability transition pore, FEBS Lett. 396, 189-195.

Bojes, H. K., Datta, K., Xu, J., Chin, A., Simonian, P., Nunez, G. \& Kehrer, J. P. (1997) $\mathrm{Bcl}_{\mathrm{L}}$ overexpression attenuates glutathione depletion in FL5.12 cells following interleukin-3 withdrawal, Biochem. J. 325, 315-319.

Borner, C., Martinou, I., Mattmann, C., Irmler, M., Schaerer, E., Martinou, J. C. \& Tschopp, J. (1994) The protein bcl-2 alpha does not require membrane attachment, but two conserved domains to suppress apoptosis, J. Cell Biol. 126, 1059-1068.

Bossy-Wetzel, E., Newmeyer, D. D. \& Green, D. R. (1998) Mitochondrial cytochrome c release in apoptosis occurs upstream of DEVD-specific caspase activation and independently of mitochondrial transmembrane depolarization, EMBO J. 17, 37-49.

Boyd, J. M., Malstrom, S., Subramanian, T., Venkatesh, L. K., Schaeper, U., Elangovan, B., D'Sa, E. C. \& Chinnadurai, G. (1994) Adenovirus E1B 19 kDa and Bcl-2 proteins interact with a common set of cellular proteins, Cell 79, 341-351. 
Cai, J. \& Jones, D. P. (1998) Superoxide in apoptosis. Mitochondrial generation triggered by cytochrome c loss, J. Biol. Chem. 273, 11401-11404.

Carayon, P., Portier, M., Dussossoy, D., Bord, A., Petitpretre, G., Canat, X., Le Fur, G. \& Casellas, P. (1996) Involvement of peripheral benzodiazepine receptors in the protection of hematopoietic cells against oxygen radical damage, Blood 87, 3170-3178.

Chauhan, D., Pandey, P., Ogata, A., Teoh, G., Krett, N., Halgren, R., Rosen, S., Kufe, D., Kharbanda, S. \& Anderson, K. (1997) Cytochrome c-dependent and -independent induction of apoptosis in multiple myeloma cells, J. Biol. Chem. 272, 29995-29997.

Chen, L. Z., Nourse, J. \& Cleary, M. L. (1989) The bcl-2 candidate protooncogene product is a 24-kilodalton integral-membrane protein highly expressed in lymphoid cell lines and lymphomas carrying the $t(14 ; 18)$ translocation, Mol. Cell. Biol. 9, 701-10.

Cheng, E. H., Levine, B., Boise, L. H., Thompson, C. B. \& Hardwick, J. M. (1996) Bax-independent inhibition of apoptosis by Bcl-x ${ }_{\mathrm{L}}$, Nature 379, 554556.

Chinnaiyan, A. M., Chaudhary, D., O'Rourke, K., Koonin, E. V. \& Dixit, V. M. (1997a) Role of CED-4 in the activation of CED-3, Nature 388, 728-729.

Chinnaiyan, A. M., O'Rourke, K., Lane, B. R. \& Dixit, V. M. (1997b) Interaction of CED-4 with CED-3 and CED-9: a molecular framework for cell death, Science 275, 1122-1126.

Cryns, V. \& Yuan, J. (1998) Proteases to die for, Genes and Dev. 12, 15511570.

Datta, S. R., Dudek, H., Tao, X., Masters, S., Fu, H., Gotoh, Y. \& Greenberg, M. E. (1997) Akt phosphorylation of BAD couples survival signals to the cellintrinsic death machinery, Cell 91, 231-241.

de Jong, D., Prins, F. A., Mason, D. Y., Reed, J. C., van Ommen, G. B. \& Kluin, P. M. (1994) Subcellular localization of the bcl-2 protein in malignant and normal lymphoid cells, Cancer Res 54, 256-60.

Decaudin, D., Geley, S., Hirsch, T., Castedo, M., Marchetti, P., Macho, A., Kofler, R. \& Kroemer, G. (1997) Bcl-2 and Bcl-X $\mathrm{L}_{\mathrm{L}}$ antagonize the mitochondrial dysfunction preceding nuclear apoptosis induced by chemotherapeutic agents, Cancer Res. 57, 62-7.

Degli Esposti, M. \& McLennan, H. (1998) Mitochondria and cells produce reactive oxygen species in virtual anaerobiosis: relevance to ceramide-induced apoptosis, FEBS Lett. 430, 338-342.

del Peso, L., Gonzalez Garcia, M., Page, C., Herrera, R. \& Nunez, G. (1997) Interleukin-3-induced phosphorylation of BAD through the protein kinase Akt, Science 278, 687-689. 
Distelhorst, C. W., Lam, M. \& McCormick, T. S. (1996) Bcl-2 inhibits hydrogen peroxide-induced ER Ca2+ pool depletion, Oncogene 12, 20512055.

Ellerby, L. M., Ellerby, H. M., Park, S. M., Holleran, A. L., Murphy, A. N., Fiskum, G., Kane, D. J., Testa, M. P., Kayalar, C. \& Bredesen, D. E. (1996) Shift of the cellular oxidation-reduction potential in neural cells expressing Bcl-2, J. Neurochem. 67, 1259-1267.

Ellis, R. E., Yuan, J. Y. \& Horvitz, H. R. (1991) Mechanisms and functions of cell death, Annu. Rev. Cell Biol. 7, 663-698.

Fernandez, S. M. \& Bischoff, J. R. (1993) Bcl-2 associates with the ras-related protein R-ras p23, Nature 366, 274-275.

France-Lanord, V., Brugg, B., Michel, P. P., Agid, Y. \& Ruberg, M. (1997) Mitochondrial free radical signal in ceramide-dependent apoptosis: a putative mechanism for neuronal death in Parkinson's disease, J Neurochem 69, 161221.

Fridovich, I. (1978) The biology of oxygen radicals, Science 201, 875-880.

Golstein, P. (1997) Controlling Cell Death, Science 275, 1081-1082.

Gonzalez-Garcia, M., Perez-Ballestero, R., Ding, L., Duan, L., Boise, L. H., Thompson, C. B. \& Nunez, G. (1994) bcl- $\mathrm{X}_{\mathrm{L}}$ is the major $b c l-x$ mRNA form expressed during murine development and its product localizes to mitochondria, Development 120, 3033-3042.

Greenlund, L. J. S., Deckwerth, T. L. \& Johnson Jr, E. M. (1995) Superoxide dismutase delays neuronal apoptosis: a role for reactive oxygen species in programmed neuronal death, Neuron 14, 303-315.

Gross, A., Jockel, J., Wei, M. C. \& Korsmeyer, S. J. (1998) Enforced dimerization of BAX results in its translocation, mitochondrial dysfunction and apoptosis, EMBO J. 17, 3878-3885.

Gudz, T. I., Tserng, K. Y. \& Hoppel, C. L. (1997) Direct inhibition of mitochondrial respiratory cahin complex III by cell-permeable ceramide, $J$. Biol. Chem. 272, 24154-24158.

Guénal, I., Sidoti-de Fraisse, C., Gaumer, S. \& Mignotte, B. (1997) Bcl-2 and Hsp27 act at different levels to suppress programmed cell death, Oncogene 15, 347-360.

Halliwell, B. \& Gutteridge, J. M. (1990) Role of free radicals and catalytic metal ions in human disease: an overview, Methods Enzymol. 1-85.

Halliwell, B. \& Gutteridge, J. M. C. (1989) Free radicals in Biology and Medecine,

Hartley, A., Stone, J. M., Heron, C., Cooper, J. M. \& Schapira, A. H. (1994) Complex I inhibitors induce dose-dependent apoptosis in PC12 cells: relevance to Parkinson's disease, J. Neurochem. 63, 1987-90. 
He, H., Lam, M., McCormick, T. S. \& Distelhorst, C. W. (1997) Maintenance of Calcium Homeostasis in the Endoplasmic Reticulum by Bcl-2, J. Cell. Biol. $138,1219-1228$.

Hengartner, M. O. (1997) Apoptosis. CED-4 is a stranger no more, Nature 388, 714-715.

Hickish, T., Robertson, D., Clarke, P., Hill, M., di Stefano, F., Clarke, C. \& Cunningham, D. (1994) Ultrastructural localization of BHRF1: an EpsteinBarr virus gene product which has homology with bcl-2, Cancer Res. 54, 2808-11.

Higuchi, M., Aggarwal, B. B. \& Yeh, E. T. (1997) Activation of CPP32-like protease in tumor necrosis factor-induced apoptosis is dependent on mitochondrial function, J. Clin. Invest. 99, 1751-1758.

Hirsch, T., Decaudin, D., Susin, S. A., Marchetti, P., Larochette, N., RescheRigon, M. \& Kroemer, G. (1998) PK11195, a ligand of the mitochondrial benzodiazepine receptor, facilitates the induction of apoptosis and reverses bcl-2-mediated cytoprotection, Exp. Cell Res. 241, 426-434.

Hockenbery, D., Nunez, G., Milliman, C., Schreiber, R. D. \& Korsmeyer, S. J. (1990) Bcl-2 is an inner mitochondrial protein that blocks programmed cell death., Nature 348, 334-336.

Hockenbery, D. M., Oltvai, Z. N., Yin, X. M., Milliman, C. L. \& Korsmeyer, S. J. (1993) Bcl-2 functions in an antioxidant pathway to prevent apoptosis, Cell 75, 241-251.

Hofmann, K., Bucher, P. \& Tschopp, J. (1997) The CARD domain: a new apoptotic signalling motif, Trensd Biochem. Sci. 22, 155-156.

Hsu, Y. T., Wolter, K. G. \& Youle, R. J. (1997) Cytosol-to-membrane redistribution of Bax and Bcl-X(L) during apoptosis, Proc. Natl. Acad. Sci. USA 94, 3668-3672.

Hu, Y., Benedict, M. A., Wu, D., Inohara, N. \& Nunez, G. (1998) Bcl-x ${ }_{\text {L }}$ interacts with Apaf-1 and inhibits Apaf-1-dependent caspase-9 activation, $J$. Biol. Chem. 273, 4386-4391.

Jacobson, M. D. (1996) Reactive oxygen species and programmed cell death, Trends Biochem. Sci. 21, 83-86.

Jacobson, M. D., Burne, J. F. \& Raff, M. C. (1994) Programmed Cell Death and Bcl-2 Protection in the Absence of a Nucleus, EMBO J. 13, 1899-1910.

Jacobson, M. D. \& Raff, M. C. (1995) Programmed cell death and Bcl-2 protection in very low oxygen, Nature 374, 814-816.

Janiak, F., Leber, B. \& Andrews, D. W. (1994) Assembly of Bcl-2 into microsomal and outer mitochondrial membranes, J. Biol. Chem. 269, 9842-9.

Jürgensmeier, J., Krajewski, S., Armstrong, R. C., Wilson, G. M., Olterdorf, T., Fritz, L. C., Reed, J. C. \& Ottilie, S. (1997) Bax- and Bak-induced cell 
death in the fission yeast Schizosaccharomyces pombe, Mol. Biol. Cell 8, 325339.

Jurgensmeier, J. M., Xie, Z., Deveraux, Q., Ellerby, L., Bredesen, D. \& Reed, J. C. (1998) Bax directly induces release of cytochrome c from isolated mitochondria, Proc. Natl. Acad. Sci. (USA) 95, 4997-5002.

Kane, D. J., Sarafian, T. A., Anton, R., Hahn, H., Gralla, E. B., Valentine, J. S., Ord, T. \& Bredesen, D. E. (1993) Bcl-2 inhibition of neural death decreased generation of reactive oxygen species, Science 262, 1274-1277.

Kharbanda, S., Pandey, P., Schofield, L., Israels, S., Roncinske, R., Yoshida, K., Bharti, A., Yuan, Z. M., Saxena, S., Weichselbaum, R., Nalin, C. \& Kufe, D. (1997) Role for bcl- $\mathrm{X}_{\mathrm{L}}$ as an inhibitor of cytosolic cytochrome C accumulation in DNA damage-induced apoptosis, Proc. Natl. Acad. Sci. USA 94, 6939-6942.

Kluck, R. M., Bossy-Wetzel, E., Green, D. R. \& Newmeyer, D. D. (1997a) The release of cytochrome $\mathrm{c}$ from mitochondria: a primary site for Bcl-2 regulation of apoptosis, Science 275, 1132-1136.

Kluck, R. M., Martin, S. J., Hoffman, B., Zhou, J. S., Green, D. R. \& Newmeyer, D. D. (1997b) Cytochrome c activation of CPP32-like proteolysis plays a critical role in a Xenopus cell-free apoptosis system, EMBO J. 16, 4639-4649.

Knudson, C. M. \& Korsmeyer, S. J. (1997) Bcl-2 and Bax function independently to regulate cell death, Nat. Genet. 16, 358-363.

Korsmeyer, S. J. (1992) Bcl-2 initiates a new category of oncogenes: regulators of cell death, Blood 80, 879-86.

Korsmeyer, S. J., Yin, X. M., Oltvai, Z. N., Veis, N. D. \& Linette, G. P. (1995) Reactive oxygen species and the regulation of cell death by the Bcl-2 gene family, Biochim. Biophys. Acta 1271, 63-66.

Krajewski, S., Tanaka, S., Takayama, S., Schibler, M. J., Fenton, W. \& Reed, J. C. (1993) Investigation of the subcellular distribution of the bcl-2 oncoprotein: residence in the nuclear envelope, endoplasmic reticulum, and outer mitochondrial membranes, Cancer Res. 53, 4701-4714.

Krippner, A., Matsuno-Yagi, A., Gootlieb, R. A. \& Babior, B. M. (1996) Loss of Function of Cytochrome $\mathrm{c}$ in Jurkat Cells Undergoing Fas-mediated Apoptosis, J. Biol. Chem. 271, 21629-21636.

Kroemer, G. (1997) The proto-oncogene Bcl-2 and its role in regulating apoptosis, Nature Med. 3, 614-620.

Kroemer, G., Petit, P. X., Zamzami, N., Vayssière, J. L. \& Mignotte, B. (1995) The biochemistry of programmed cell death, FASEB J. 9, 1277-1287.

Kroemer, G., Zamzami, N. \& Susin, S. A. (1997) Mitochondrial control of apoptosis, Immunol. Today 18, 44-51. 
Kurschner, C. \& Morgan, J. I. (1995) The cellular prion protein (PrP) selectively binds to Bcl-2 in the yeast two-hybrid system, Mol. Brain Res 30, 165-168.

Lam, M., Dubyak, G., Chen, L., Nunez, G., Miesfeld, R. L. \& Distelhorst, C. W. (1994) Evidence that BCL-2 represses apoptosis by regulating endoplasmic reticulum-associated Ca2+ fluxes, Proc. Natl. Acad. Sci. USA 91, 6569-6573.

Lancaster, J. R., Laster, S. M. \& Gooding, L. R. (1989) Inhibition of target cell mitochondrial electron transfer by tumor necrosis factor, FEBS Lett. 248, 169174.

Lennon, S. V., Martin, S. J. \& Cotter, T. G. (1991) Dose-dependent induction of apoptosis in human tumour cell lines by widely diverging stimuli, Cell Prolif. 24, 203-14.

Li, F., Srinivasan, A., Wang, Y., Armstrong, R. C., Tomaselli, K. J. \& Fritz, L. C. (1997a) Cell-specific Induction of Apoptosis by Microinjection of Cytochrome c. Bcl-xl has activity independent of cytochrome c release, $J$. Biol. Chem. 272, 30299-30305.

Li, H., Zhu, H. \& yuan, J. (1998) Cleavage of BID by Caspase 8 Mediates the Mitochondrial Damage in th Fas Pathway of Apoptosis, Cell 94,

Li, P., Nijhawan, D., Budihardjo, I., Srinivasula, S. M., Ahmad, M., Alnemri, E. S. \& Wang, X. (1997b) Cytochrome c and dATP-Dependent Formation of Apaf-1/Caspase-9 Complex Initiates an Apoptotic Protease Cascade, Cell 91, 479-489.

Liu, X., Kim, C. N., Yang, J., Jemmerson, R. \& Wang, X. (1996) Induction of apoptotic program in cell-free extracts: requirement for dATP and cytochrome c, Cell 86, 147-157.

Longo, V. D., Ellerby, L. M., Bredesen, D. E., Valentine, J. S. \& Gralla, E. B. (1997) Human Bcl-2 reverses survival defects in yeast lacking superoxide dismutase and delays death of wild-type yeast, J. Cell Biol. 137, 1581-8.

Luo, X., Budihardjo, I., Zou, H., Slaughter, C. \& Wang, X. (1998) Bid, a Bcl2 Interacting Protein, Mediates Cytochrome c release from Mitochondria in Response to Activation of Cell surface Death receptors, Cell 94, 481-490.

Macho, A., Hirsch, T., Marzo, I., Marchetti, P., Dallaporta, B., Susin, S. A., Zamzami, N. \& Kroemer, G. (1997) Glutathione depletion is an early and calcium elevation is a late event of thymocyte apoptosis, J. Immunol. 158, 4612-4619.

Madeo, F., Frohlich, E. \& Frohlich, K. U. (1997) A yeast mutant showing diagnostic markers of early and late apoptosis, J. Cell Biol. 139, 729-734.

Manon, S., Chaudhuri, B. \& Guerin, M. (1997) Release of cytochrome c and decrease of cytochrome c oxidase in Bax- expressing yeast cells, and prevention of these effects by coexpression of Bcl-xL, FEBS Lett. 415, 29-32. 
Marchetti, P., Decaudin, D., Macho, A., Zamzami, N., Hirsch, T., Susin, S. A. \& Kroemer, G. (1997) Redox regulation of apoptosis: impact of thiol oxidation status on mitochondrial function, Eur. J. Immunol. 27, 289-96.

Martin, S. J. \& Cotter, T. G. (1991) Ultraviolet B irradiation of human leukaemia HL-60 cells in vitro induces apoptosis, Int. J. Radiat. Biol. 59, 1001.

Marton, A., Mihalik, R., Bratincsak, A., Adleff, V., Petak, I., Vegh, M., Bauer, P. I. \& Krajcsi, P. (1997) Apoptotic cell death induced by inhibitors of energy conservation--Bcl- 2 inhibits apoptosis downstream of a fall of ATP level, Eur. J. Biochem. 250, 467-475.

Mayer, A., Neupert, W. \& Lill, R. (1995) Translocation of Apocytochrome c accross the Outer membrane of Mitochondria, J. Biol. Chem. 270, 1239012397.

Mayer, M. \& Noble, M. (1994) N-acetyl-L-cysteine is a pluripotent protector against cell death and enhancer of trophic factor-mediated cell survival in vitro, Proc. Nathl. Acad. Sci. USA 91, 7496-500.

Mehlen, P., Schulze-Osthoff, K. \& Arrigo, A. P. (1996) Small stress proteins as novel regulators of apoptosis, J. Biol. Chem. 271, 16510-16514.

Mignotte, B., Larcher, J. C., Zheng, D. Q., Esnault, C., Coulaud, D. \& Feunteun, J. (1990) SV40 induced cellular immortalization : phenotypic changes associated with the loss of proliferative capacity in a conditionally immortalized cell line, Oncogene 5, 1529-1533.

Mignotte, B. \& Vayssière, J. L. (1998) Mitochondria and apoptosis, Eur. J. Biochem. 252, 1-15.

Minn, A. J., Velez, P., Schendel, S. L., Liang, H., Muchmore, S. W., Fesik, S. W., Fill, M. \& Thompson, C. B. (1997) Bcl- ${ }_{\mathrm{L}}$ forms an ion channel in synthetic lipid membranes, Nature 385, 353-357.

Mirkovic, N., Voehringer, D. W., Story, M. D., McConkey, D. J., McDonnell, T. J. \& Meyn, R. E. (1997) Resistance to radiation-induced apoptosis in Bcl-2expressing cells is reversed by depleting cellular thiols, Oncogene 15, 14611470.

Muchmore, S. W., Sattler, M., Liang, H., Meadows, R. P., Harlan, J. E., Yoon, H. S., Nettesheim, D., Chang, B. S., Thompson, C. B., Wong, S. L., Ng, S. C. \& Fesik, S. W. (1996) X-ray and NMR structure of human Bcl-X $\mathrm{L}_{\mathrm{L}}$, an inhibitor of programmed cell death, Nature 381, 335-341.

Myers, K. M., Fiskum, G., Liu, Y., Simmens, S. J., Bredesen, D. E. \& Murphy, A. N. (1995) Bcl-2 protects neural cells from cyanide/aglycemiainduced lipid oxidation, mitochondrial injury, and loss of viability, $J$. Neurochem. 65, 2432-2440.

Nagata, S. (1997) Apoptosis by Death Factor, Cell 88, 355-365. 
Nakai, M., Takeda, A., Cleary, M. L. \& Endo, T. (1993) The bcl-2 protein is inserted into the outer membrane but not into the inner membrane of rat liver mitochondria in vitro, Biochem. Biophys. Res. Commun. 196, 233-239.

Naumovski, L. \& Cleary, M. L. (1996) The p53-binding protein 53BP2 also interacts with Bcl-2 and impedes cell cycle progression at G2/M, Mol Cell Biol 16, 3884-92.

Newmeyer, D. D., Farschon, D. M. \& Reed, J. C. (1994) Cell-free apoptosis in Xenopus egg extracts: inhibition by Bcl-2 and requirement for an organelle fraction enriched in mitochondria, Cell 79, 353-364.

Nguyen, M., Branton, P. E., Walton, P. A., Oltvai, Z. N., Korsmeyer, S. J. \& Shore, G. C. (1994) Role of membrane anchor domain of Bcl-2 in suppression of apoptosis caused by E1B-defective adenovirus, J. Biol. Chem. 269, 1652116524.

Nguyen, M., Millar, D. G., Yong, V. W., Korsmeyer, S. J. \& Shore, G. C. (1993) Targeting of bcl-2 to the mitochondrial outer membrane by a COOHTerminal signal anchor sequence, J. Biol. Chem. 268, 25265-25268.

Nicholson, D. W. \& Thornberry, N. A. (1997) Caspases: killer proteases, Trends Biochem. Sci. 22, 299-306.

O'Donnell, V. B., Spycher, S. \& Azzi, A. (1995) Involvement of oxidants and oxidant-generating enzyme(s) in tumour- necrosis-factor-alpha-mediated apoptosis: role for lipoxygenase pathway but not mitochondrial respiratory chain, Biochem J 310, 133-141.

Olivier, R., Otter, I., Monney, L., Wartmann, M. \& Borner, C. (1997) Bcl-2 does not require Raf kinase activity for its death-protective function, Biochem. J. 324, 75-83.

Oltvai, Z. N., Milliman, C. L. \& Korsmeyer, S. J. (1993) bcl-2 heterodimerizes in vivo with a conserved homolog, bax, that accelerates programmed cell death, Cell 74, 609-619.

Pan, G., O'Rourke, K. \& Dixit, V. M. (1998) Caspase-9, Bcl-x L, and Apaf-1 Form a Ternary Complex, J. Biol. Chem. 273, 5841-5845.

Pastorino, J. G., Chen, S. T., Tafani, M., Snyder, J. W. \& Farber, J. L. (1998) The overexpression of Bax produces cell death upon induction of the mitochondrial permeability transition, J. Biol. Chem. 273, 7770-5.

Paumen, M. B., Ishida, Y., Han, H., Muramatsu, M., Eguchi, Y., Tsujimoto, Y. \& Honjo, T. (1997) Direct interaction of the mitochondrial membrane protein carnitine palmitoyltransferase I with Bcl-2, Biochem. Biophys. Res. Commun. 231, 523-525.

Petit, P. X., Goubern, M., Diolez, P., Susin, S. A., Zamzami, N. \& Kroemer, G. (1998) Disruption of the outer mitochondrial membrane as a result of large amplitude swelling: the impact of irreversible permeability transition, FEBS Lett. 426, 111-116. 
Petit, P. X., Lecoeur, H., Zorn, E., Dauguet, C., Mignotte, B. \& Gougeon, M. L. (1995) Alterations in mitochondrial structure and function are early events of dexamethasone-induced thymocytes apoptosis, J. Cell Biol. 130, 157-167.

Petronilli, V., Nicolli, A., Costantini, P., Colonna, R. \& Bernardi, P. (1994) Regulation of the permeability transition pore, a voltage-dependent mitochondrial channel inhibited by cyclosporin A., Biochem. Biophys. Acta 1187, 255-259.

Pinkus, R., Weiner, L. M. \& Daniel, V. (1996) Role of Oxidants and Antioxidants in the Induction of AP-1, NF-kB, and Glutathione S-Transferase Gene Expression., J. Biol. Chem. 271, 13422-13429.

Quillet-Mary, A., Jaffrezou, J. P., Mansat, V., Bordier, C., Naval, J. \& Laurent, G. (1997) Implication of mitochondrial hydrogen peroxide generation in ceramide- induced apoptosis, J. Biol. Chem. 272, 21388-95.

Ratan, R. R., Murphy, T. H. \& Baraban, J. M. (1994) Oxidative stress induces apoptosis in embryonic cortical neurons, J. Neurochem. 62, 376-9.

Reed, J. C. (1997) Double identity for proteins of the Bcl-2 family, Nature 387, 773-776.

Rosse, T., Olivier, R., Monney, L., Rager, M., Conus, S., Fellay, I., Jansen, B. $\&$ Borner, C. (1998) Bcl-2 prolongs cell survival after Bax-induced release of cytochrome c, Nature 391, 496-499.

Ryan, J. J., Prochownik, E., Gottlieb, C. A., Apel, I. J., Merino, R., Nunez, G. \& Clarke, M. F. (1994) c-myc and bcl-2 modulate p53 function by altering p53 subcellular trafficking during the cell cycle, Proc. Natl. Acad. Sci. USA 91, 5878-5882.

Sandstrom, P. A. \& Buttke, T. M. (1993) Autocrine production of extracellular catalase prevents apoptosis of the human CEM T-cell line in serum-free medium, Proc. Natl. Acad. Sci. USA 90, 4708-12.

Sato, N., Iwata, S., Nakamura, K., Hori, T., Mori, K. \& Yodoi, J. (1995) Thiol-Mediated Redox Regulation of Apoptosis. Possible roles of cellular thiols other than glutathione in T cell apoptosis, J. Immunol. 154, 3194-3203.

Scarlett, J. L. \& Murphy, M. P. (1997) Release of apoptogenic proteins from the mitochondrial intermembrane space during the mitochondrial permeability transition, FEBS Lett. 418, 282-286.

Schendel, S. L., Xie, Z., Montal, M. O., Matsuyama, S., Montal, M. \& Reed, J. C. (1997) Channel formation by antiapoptotic protein Bcl-2, Proc. Natl. Acad. Sci. USA 94, 5113-8.

Schulze-Osthoff, K., Bakker, A. C., Vanhaesebroeck, B., Beyaert, R., Jacob, W. A. \& Fiers, W. (1992) Cytotoxic activity of tumor necrosis factor is mediated by early damage of mitochondrial functions. Evidence for the involvement of mitochondrial radical generation, J. Biol. Chem. 267, 53175323. 
Schulze-Osthoff, K., Beyaert, R., Vandevoorde, V., Haegeman, G. \& Fiers, W. (1993) Depletion of the mitochondrial electron transport abrogates the cytotoxic and Gene-Inductive effects of TNF, EMBO J. 12, 3095-3104.

Schulze-Osthoff, K., Ferrari, D., Los, M., Wesselborg, S. \& Peter, M. E. (1998) Apoptosis signaling by death receptors, Eur. J. Biochem. 254, 439-459.

Schulze-Osthoff, K., Krammer, P. H. \& Droge, W. (1994) Divergent signalling via APO-1/Fas and the TNF receptor, two homologous molecules involved in physiological cell death, EMBO J. 13, 4587-4596.

Sedlak, T. W., Oltvai, Z. N., Yang, E., Wang, K., Boise, L. H., Thompson, C. B. \& Korsmeyer, S. J. (1995) Multiple Bcl-2 family members demonstrate selective dimerizations with Bax, Proc. Natl. Acad. Sci. USA 92, 7834-7838.

Shaham, S. \& Horvitz, H. R. (1996) Developing Caenorhabditis elegans neurons may contain both cell-death protective and killer activities, Genes Dev. 10, 578-591.

Shibasaki, F., Kondo, E., Akagi, T. \& McKeon, F. (1997) Suppression of signalling through transcription factor NF-AT by interactions between calcineurin and Bcl-2, Nature 386, 728-731.

Shimizu, S., Eguchi, Y., Kamiike, W., Funahashi, Y., Mignon, A., Lacronique, V., Matsuda, H. \& Tsujimoto, Y. (1998) Bcl-2 prevents apoptotic mitochondrial dysfunction by regulating proton flux, Proc. Natl. Acad. Sci. (USA) 95, 1455-1459.

Shimizu, S., Eguchi, Y., Kosaka, H., Kamiike, W., Matsuda, H. \& Tsujimoto, Y. (1995) Prevention of hypoxia-induced cell death by Bcl-2 and Bcl-X $\mathrm{L}_{\mathrm{L}}$, Nature 374, 811-813.

Sidoti-de Fraisse, C., Rincheval, V., Risler, Y., Mignotte, B. \& Vayssière, J. L. (1998) TNF- $\alpha$ activates at least two apoptotic signaling cascades, Oncogene Sous presse.

Sies, H. (1991) Oxidative stress: from basic research to clinical application, Am. J. Med. 91, 31S-38S.

Skulachev, V. P. (1998) Cytochrome c in the apoptotic and antioxidant cascades, FEBS Lett. 423, 275-280.

Susin, S. A., Zamzani, N., Castedo, M., Hirsh, T., Marchetti, P., Macho, A., Daugas, E., Geuskens, M. \& Kroemer, G. (1996) Bcl-2 inhibits the mitochondrial release of an apoptogenic protease, J. Exp. Med. 184, 1-11.

Takayama, S., Sato, T., Krajewski, S., Kochel, K., Irie, S., Millan, J. A. \& Reed, J. C. (1995) Cloning and functional analysis of BAG-1: a novel Bcl-2binding protein with anti-cell death activity, Cell 80, 279-284.

Tang, D. G., Li, L., Zhu, Z. \& Joshi, B. (1998) Apoptosis in the absence of cytochrome $\mathrm{c}$ accumulation in the cytosol [In Process Citation], Biochem. Biophys. Res. Commun. 242, 380-384. 
Tyurina, Y. Y., Tyurin, V. A., Carta, G., Quinn, P. J., Schor, N. F. \& Kagan, V. E. (1997) Direct evidence for antioxidant effect of Bcl-2 in PC12 rat pheochromocytoma cells, Arch. Biochem. Biophys. 344, 413-423.

Uckun, F. M., Tuelahlgren, L., Song, C. W., Waddick, K., Myers, D. E., Kirihara, J., Ledbetter, J. A. \& Schieven, G. L. (1992) Ionizing radiation stimulates unidentified Tyrosine-Specific protein kinases in human Lymphocyte-B precursors, triggering apoptosis and clonogenic cell death, Proc. Natl. Acad. Sci. USA 89, 9005-9009.

van den Dobbelsteen, D. J., Nobel, C. S. I., Schlegel, J., Cotgreave, I. A., Orrenius, S. \& Slater, A. F. G. (1996) Rapid and Specific Efflux of Reduced Glutathione during Apoptosis Induced by Anti-Fas/APO-1 Antibody, J. Biol. Chem. 271, 15420-15427.

Van der Heiden, M. G., Chandel, N. S., Williamson, E. K., Schumacker, P. T. \& Thompson, C. B. (1997) Bcl-xL regulates the membrane potential and volume homeostasis of mitochondria, Cell 91, 627-637.

Vayssière, J. L., Petit, P. X., Risler, Y. \& Mignotte, B. (1994) Commitment to apoptosis is associated with changes in mitochondrial biogenesis and activity in cell lines conditionally immortalized with Simian Virus 40, Proc. Natl. Acad. Sci. USA 91, 11752-11756.

Veis, D. J., Sorenson, C. M., Shutter, J. R. \& Korsmeyer, S. J. (1993) Bcl-2Deficient mice demonstrate fulminant lymphoid apoptosis, polycystic kidneys, and hypopigmented hair, Cell 75, 229-240.

Wang, H., Rapp, U. R. \& Reed, J. C. (1996a) Bcl-2 Targets the Protein Kinase Raf-1 to Mitochondria, Cell 87, 629-638.

Wang, H. G., Miyashita, T., Takayama, S., Sato, T., Torigoe, T., Krajewski, S., Tanaka, S., Hovey, L. r., Troppmair, J., Rapp, U. R. \& Reed, J. C. (1994) Apoptosis regulation by interaction of $\mathrm{Bcl}-2$ protein and Raf-1 kinase, Oncogene 9, 2751-2756.

Wang, H. G., Takayama, S., Rapp, U. R. \& Reed, J. C. (1996b) Bcl-2 interacting protein, BAG-1, binds to and activates the kinase Raf- 1, Proc. Natl. Acad. Sci. USA 93, 7063-7068.

Wang, X. \& Studzinski, G. P. (1997) Antiapoptotic action of 1,25dihydroxyvitamin D3 is associated with increased iitochondrial MCL-1 and RAF-1 proteins and reduced release of cytochrome c, Exp. Cell. Res. 235, 210-7.

Wolvetang, E. J., Johnson, K. L., Krauer, K., Ralph, S. J. \& Linnane, A. W. (1994) Mitochondrial respiratory chain inhibitors induce apoptosis, FEBS Lett. $339,40-44$.

Wong, G. H. W., Elwell, J. H., Oberley, L. W. \& Goeddel, D. V. (1989) Manganous superoxide dismutase is essential for cellular resistance to cytotoxicity of tumor necrosis factor, Cell 58, 923-931. 
Wu, D., Wallen, H. D., Inohara, N. \& Nunez, G. (1997a) Interaction and regulation of the Caenorhabditis elegans death protease CED-3 by CED-4 and CED-9, J. Biol. Chem. 272, 21449-21454.

Wu, D., Wallen, H. D. \& Nunez, G. (1997b) Interaction and regulation of subcellular localization of CED-4 by CED-9, Science 275, 1126-1129.

Xiang, J., Chao, D. T. \& S.J., K. (1996) BAX-induced cell death may not require interleukin $1 \beta$-converting enzyme-like proteases, Proc. Natl. Acad. Sci. USA 93, 14559-14563.

Yang, J., Liu, X., Bhalla, K., Kim, C. N., Ibrado, A. M., Cai, J., Peng, T. I., Jones, D. P. \& Wang, X. (1997) Prevention of apoptosis by Bcl-2: release of cytochrome c from mitochondria blocked, Science 275, 1129-1132.

Yang, T., Kozopas, K. M. \& Craig, R. W. (1995) The intracellular distribution and pattern of expression of Mcl-1 overlap with, but are not identical to, those of Bcl-2, J. Cell Biol. 128, 1173-1184.

Yang, X., Chang, H. Y. \& Baltimore, D. (1998) Essential role of CED-4 oligomerization in CED-3 activation and apoptosis [see comments], Science 281, 1355-7.

Zamzami, N., Brenner, C., Marzo, I., Susin, S. A. \& Kroemer, G. (1998) Subcellular and submitochondrial mode of action of Bcl-2-like oncoproteins, Oncogene 16, 2265-2282.

Zamzami, N., Marchetti, P., Castedo, M., Decaudin, D., Macho, A., Petit, P. X., Mignotte, B. \& Kroemer, G. (1995a) Sequential reduction of mitochondrial transmembrane potential and generation of reactive oxygen species in early programmed cell death, J. Exp. Med. 182, 367-377.

Zamzami, N., Marchetti, P., Castedo, M., Hirsch, T., Susin, S. A., Masse, B. \& Kroemer, G. (1996a) Inhibitors of permeability transition interfere with the disruption of the mitochondrial transmembrane potential during apoptosis, FEBS Lett. 384, 53-57.

Zamzami, N., Marchetti, P., Castedo, M., Zanin, C., Vayssière, J. L., Petit, P. X. \& Kroemer, G. (1995b) Reduction in mitochondrial potential constitutes an early irreversible step of programmed lymphocyte death in vivo, J. Exp. Med. $181,1661-1672$.

Zamzami, N., Susin, S. A., Marchetti, P., Hirsch, T., Gomez-Monterrey, I., Castedo, M. \& Kroemer, G. (1996b) Mitochondrial control of nuclear apoptosis, J. Exp. Med. 183, 1533-1544.

Zhivotovsky, B., Orrenius, S., Brugstugun, O. T. \& Doskeland, S. O. (1998) Injected cytochrome c induces apoptosis, Nature 391, 449-450.

Zhong, L. T., Sarafian, T., Kane, D. J., Charles, A. C., Mah, S. P., Edwards, R. H. \& Bredesen, D. E. (1993) bcl-2 inhibits death of central neural cells induced by multiple agents, Proc. Natl. Acad. Sci. USA 90, 4533-4537.

Zhu, W., Cowie, A., Wasfy, G. W., Penn, L. Z., Leber, B. \& Andrews, D. W. (1996) Bcl-2 mutants with restricted subcellular location reveal spatially 
distinct pathways for apoptosis in different cell types, EMBO J. 15, 41304141.

Zou, H., Henzel, W. J., Liu, X., Lutschg, A. \& Wang, X. (1997) Apaf-1, a human protein homologous to $\mathrm{C}$. elegans CED-4, participates in cytochrome c-dependent activation of caspase-3, Cell 90, 405-413. 


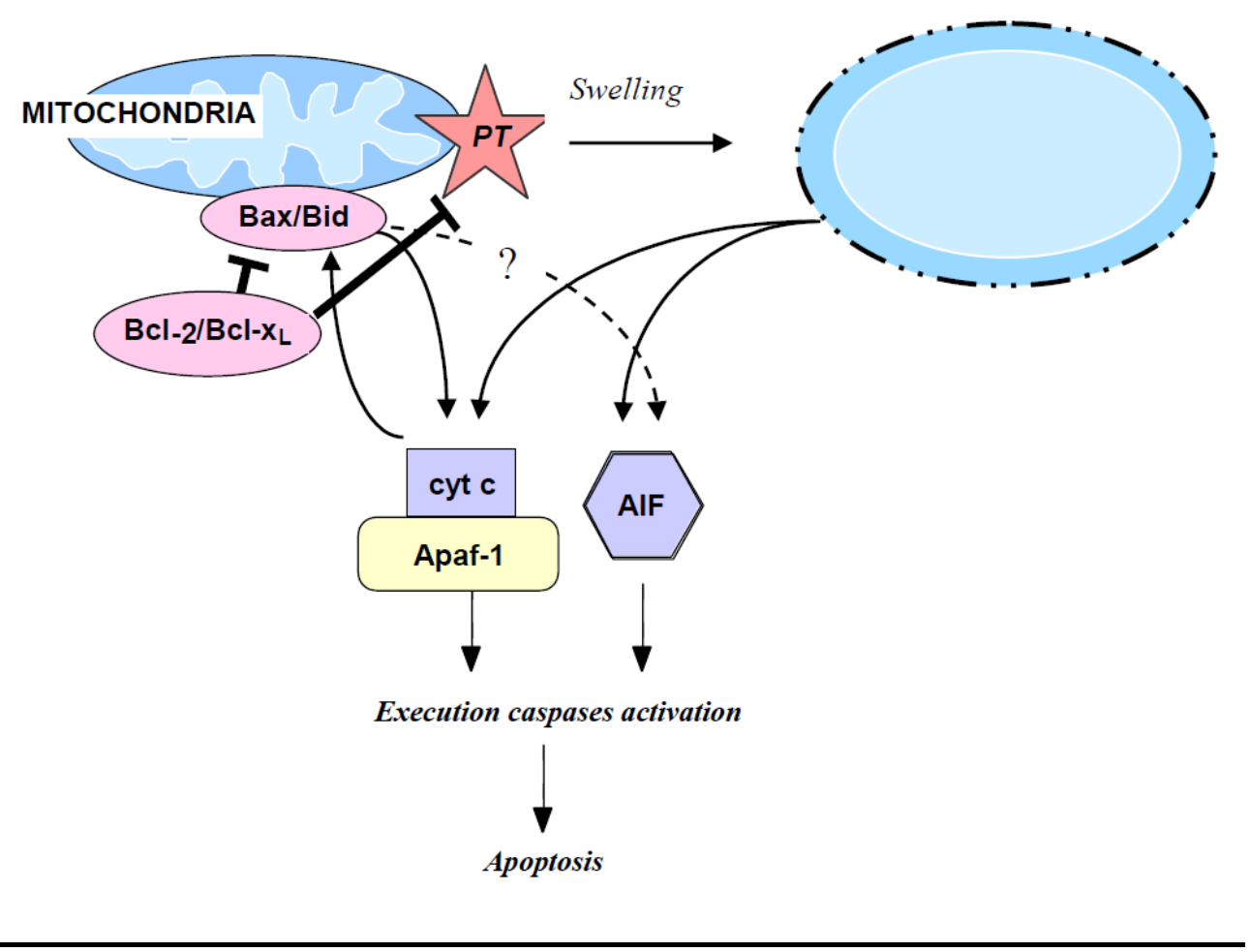

Figure 1. Simplified model of events occurring during apoptosis

Numerous signals can lead to apoptosis. The induction pathways seem to converge to events involving mitochondria. Proteins of the Bcl-2 family act on mitochondrial membrane permeability and regulate the release of proapoptotic factors from the intermembrane space to the cytosol.. These factors, directly or indirectly activate execution caspases responsible for the apoptotic phenotype. 


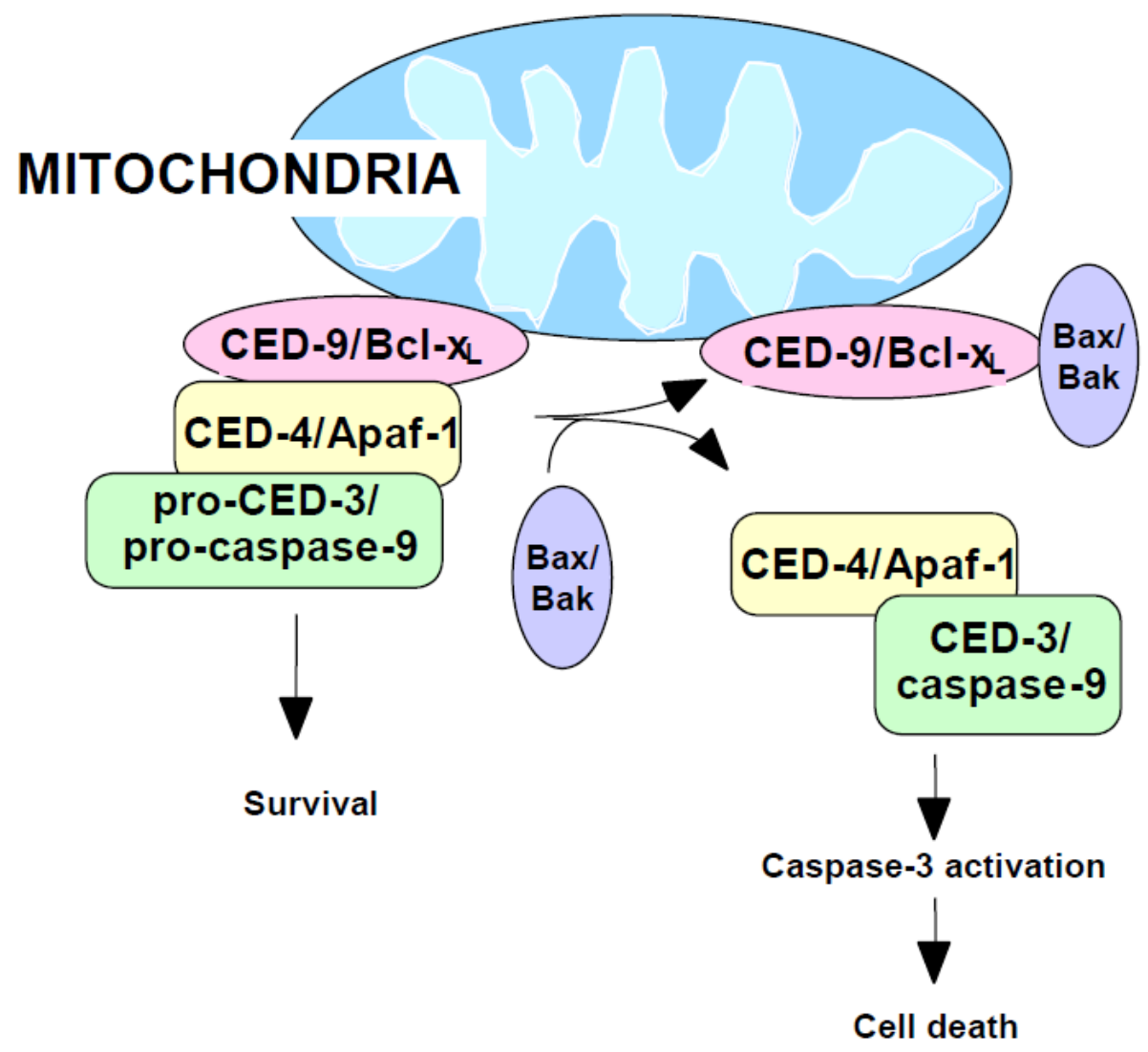

Figure 2. Bcl-2 family proteins regulates the intracellular localization and the activity of caspases containing complexes

In $C$. elegans, CED-9 might maintain CED-4/CED-3 complexes at the level of intracellular membranes by its simultaneous binding to mitochondrial membrane and CED-4. Similarly, in mammals, Bcl- $\mathrm{X}_{\mathrm{L}}$ might anchor Apaf-1/caspase complexes and keep them in an inactive state. The dissociation of the Bcl- $\mathrm{X}_{\mathrm{L}} / \mathrm{Apaf}-1$ interaction by Bax or Bak (or other proapoptotic Bcl-2 family protein) leads to the activation of caspases. 


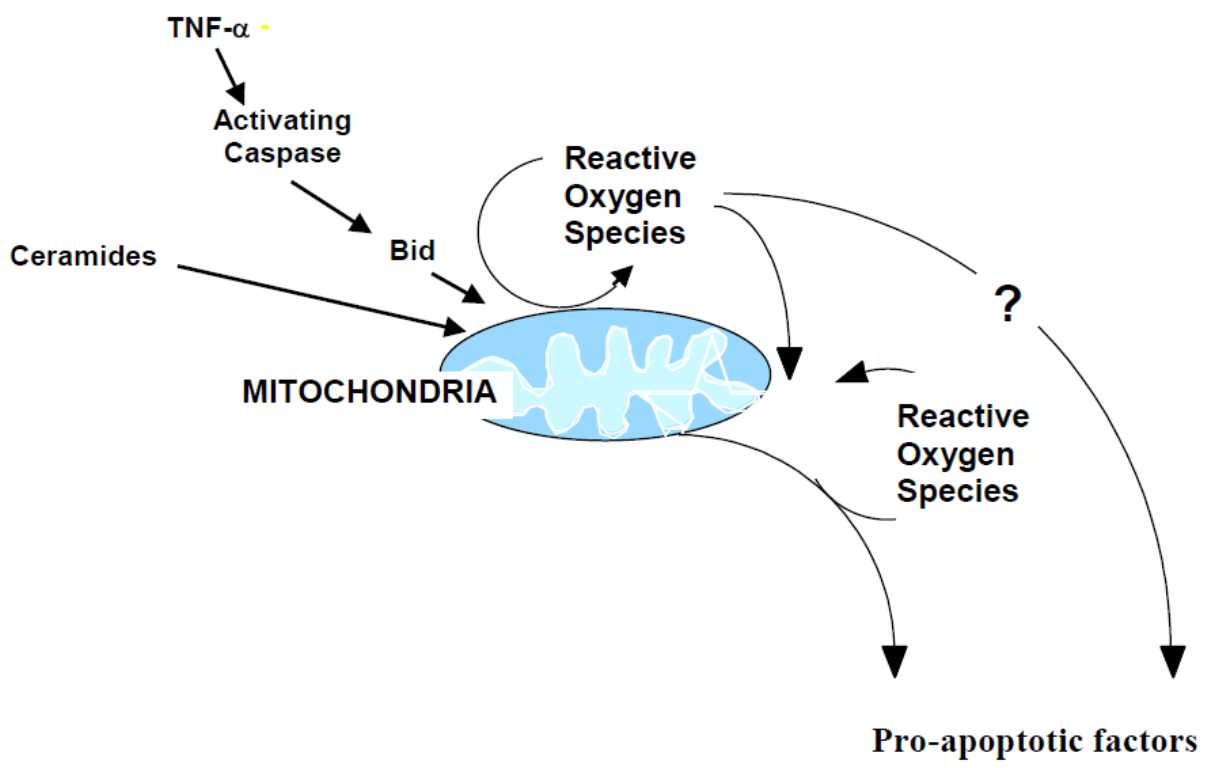

Figure 3. Mitochondrial ROS contribute to apoptosis signaling

In some cases, as during TNF- $\alpha$ - or ceramide-induced apoptosis, a ROS production is involved in apoptosis signaling. ROS accumulate as a result of a dysfunction of the mitochondrial respiratory chain and contribute to the activation of execution caspases. 


\section{C.elegans Mammals}

CED-3 Activation caspases: caspase-1 (ICE), -4 (ICH-2), -6 (Mch2), -8 $(\mathrm{MACH} / \mathrm{FLICE}) \ldots$

Execution caspases: caspase-2 (ICH-1), -3 (CPP32), -4 (ICH-2), -7 (ICE-LAP3)...

CED-4 Apaf-1

CED-9(Li et Anti-apoptotic: Bcl-2, Bcl-x $\mathrm{x}_{\mathrm{L}}$, Bcl-w, Bfl-1, Brag-1, Mcl-1, A1, al., 1997b) NR13...

Pro-apoptotic: Bax, Bak, Bcl-xs, Bad, Bik, Hrk...

Table I: Programmed cell death in nematodes and mammals is controlled by homologous proteins. Mammalian caspases act either during the activation or the execution phase of PCD (Nicholson and Thornberry, 1997). Recently, a CED-4 homologue has been identified in human cells (Hofmann et al., 1997; Zou et al., 1997). In mammals some members of the Bcl-2 related proteins are death antagonists while other are death agonists. For a recent review on the structure-function relations of Bcl-2 related proteins see (Kroemer, 1997). 